\title{
INTERPRETING THE CANADIAN CHARTER OF RIGHTS AND FREEDOMS: APPLYING INTERNATIONAL AND EUROPEAN JURISPRUDENCE ON THE LAW AND PRACTICE OF FUNDAMENTAL RIGHTS
}

\author{
ERROL P. MENDES*
}

Since the arrival of the Canadian Charter of Rights and Freedoms, there has been much discussion of applying the United States experience with its Bill of Rights to the interpretation of the Canadian Charter. It is the author's thesis, however. that Canadians ought to study the European and United Nations jurisprudence in the area of human rights documents as these documents more closely resemble the Canadian Charter than does the American Bill of Rights. Some illustrative fundamental rights cases from the United Nations and Europe are discussed. Further, the appendices include the full texts of the International Covenant on Civil and Political Rights, the European Convention for the Protection of Human Rights and Fundamental Freedoms and the Canadian Charter of Rights and Freedoms for comparative purposes.

\section{THE UNITED NATIONS EXPERIENCE}

Until the end of World War II, human rights was not universally considered to be a proper subject of international or supranational law. The prevailing theory was the absolute sovereignty of the nation state and the concomitant principle that such sovereign states could treat their own nationals in any manner they liked. ${ }^{1}$ But the situation at the international level before World War II did not prevent fundamental rights theories from existing within the sovereign state. The various philosophies which insisted that citizens in a state possess certain fundamental rights which took precedence to the power of the state to do as it liked, were the cause of many revolutions against monarchies, autocracies and dictatorships in Europe and elsewhere. ${ }^{2}$

Thus, philosophy and revolution nurtured the creation of a law of fundamental rights in the civilized world. If there is a law of fundamental

* Assistant Professor, Faculty of Law, University of Alberta.

1. The traditional positivist view espoused by Oppenhiem, among others, /see Oppenhiem, International Law (1903) 344) was that individuals were merely objects of international law which imposed no rights or duties on them. For an excellent discussion of the development of the international law of human rights before and after World War II, see John P. Humphrey "The International Law of Human Rights in the Middle Twentieth Century" in The Present State of International Law and other Essays (1973) 75, reprinted in B. Lillich \& F. Newman, International Human Rights: Problems of Law and Policy (1979). However, it must be noted that the earliest writers on international law gave serious thought to the creation of international principles governing fundamental human rights. Grotius, writing in 1650 , claimed that the principle of humanitarian intervention for the protection of fundamental rights existed as a rule of international law. See Grotius, De Jure Belli ac Pacis (1814 trans. A. C. Campbell).

2. The concept of 'natural law' which was superior to 'positive law' was at the root of these revolutionary philosophies. One of the earliest exponents of the "natural law' theory was Cicero. See De Republica. III and XXII at 33. Later in the 16 th and 17 th centuries, the doctrine of the social contract between individuals and government in the civil society was developed from the 'natural law' theory. Failure by government to observe fundamental rights would result in the rescission of the contract and ensuing disobedience and perhaps rebellion. See John Locke, Civil Government (Book II) and Rousseau, The Social Contract and Discourses (Book II). The writings of Locke and other 'natural law' advocates had a profound influence on the civilized world culminating in the American and French Revolutions. These revolutions resulted in the two most historic constitutional documents protecting fundamental rights; i.e., The American Bill of Rights of December 15, 1791 and The French Declaration of the Rights of Man and the Citizen of August 26, 1789. 
human rights, to what extent should these rights be subjected to the will of the community, and when should individual freedoms be sacrificed for the common good? This question has troubled philosophers and governments alike over the centuries, and causes severe problems particularly at the international level. This is because the philosophy of socialist and developing countries tends toward the view that societal values, such a wealth redistribution and economic progress, may justify the repression of individual freedoms. ${ }^{3}$ The pithy question that sums up the conflict is 'What can a starving man do with the freedom of expression?'

At the end of World War II, the belief that countries which violated fundamental human rights were most likely to cause wars, as was demonstrated by Nazi Germany, led to the most important General Assembly resolution on fundamental rights. This was called the Universal Declaration of Human Rights and was passed by the General Assembly of the U.N. on December 10,1948 , by a vote of 48 for and none against with only 8 members abstaining. ${ }^{4}$ The Universal Declaration of Human Rights, being a General Assembly resolution, is not technically legally binding in international law, but many of its provisions have come to be regarded as declaratory of general principles of international law relating to fundamental freedoms.

The Universal Declaration of Human Rights served as a model for the drafters of the European Convention on Human Rights and Fundamental Freedoms which is probably the most effective international agreement for the protection of human rights. ${ }^{6}$ In fact, studies undertaken by the United Nations have discovered that many constitutional documents on human rights around the world were either wholly or in part inspired by

3. For an interesting discussion of the theoretical bases of the protection of human rights by some Socialist and Third World writers, see Human Rights: Comments and Inter. pretation (1949 ed. U.N.E.S.C.O.).

4. U.N. Doc. A/777, reprinted in [1948]U.N. Yr. Bk. 465. The countries that abstained were Byelorussia, Czechoslovakia, Honduras, Poland, Ukraine, Soviet Union, South Africa and Yugoslavia. Saudi Arabia was absent.

5. While General Assembly resolutions are not binding in international law, where there seems a global consensus on basic principles, such as those enumerated in the Universal Declaration, General Assembly resolutions will inevitably affect the attitude and actions of the global community and may evolve into customary or general principles of international law. For eminent jurists supporting the view, see Schacter, "The Relation of Law, Politics and Action in the United Nations" (1963) 109 Academie de Droit Interna. tional Recueil des Cours 165 at 181-184; R. Higgins, The Development of International Law Through the Political Organs of the United Nations (1963); White, "A New International Economic Order?" (1976) 16 Va. J. Int 'l L. 323, 330; J. Castaneda, Legal Effects of United Nations Resolutions (1969); Falk, "The Quasi-Legislative Competence of the General Assembly" (1966) $60 \mathrm{Am}$. J. Int' $\mathrm{l}$ L. 702. In 1974 the General Assembly also passed a resolution which declared that "the development of International Law may be reflected, inter alia by declarations and resolutions of the General Assembly which may to that extent be taken into consideration by the International Court of Justice ...., see 29 U.N. GAOR. Supp. (No. 31) 141, U.N. Doc. A/9631 (1974), reprinted in (1975) 69 A m. J. Int $l$ L. 249. The Proclamation of Teheran reaffirmed that the Universal Declaration of Human Rights placed "an obligation" on members of the international community, see "Final Act of the International Conference on Human Rights, Teheran," U.N. Doc. A/cont 32/41, U.N. Pub. Sales No. E.68 XIV.2. The Proclamation of Teheran was endorced by the General Assembly "as an important and timely reaffirmation of the principles embodied in the Universal Declarations of Human Rights and in other international instruments in the field of Human Rights." G.A. Res. No. 2442 (XXIII) Dec. 19, 1968. 
the Universal Declaration of Human Rights. ${ }^{7}$ Today, one could add Canada to that list of countries, as there are rights laid down in the Canadian Charter which clearly correspond to the rights in the Universal Declaration and the European Convention of Human Rights. ${ }^{8}$ Moreover, the wording by which some rights are formulated in all three documents is very similar.

Not surprisingly, implementation of the law of fundamental human rights at the international level has proved exceedingly difficult. ${ }^{9}$ There is an obligation on all members of the U.N., as stated both in the preamble and Article 1 of the U.N. Charter, ${ }^{10}$ to promote and encourage respect for human rights and fundamental freedoms for all without distinction as to race, sex, language or religion. Canada is legally bound by Articles 55 and 56 of the U.N. Charter which require member countries to promote universal respect for and observance of human rights and fundamental freedoms. ${ }^{11}$

Pursuant to the principles laid down by the Universal Declaration of Human Rights and the U.N. Charter, the United Nations began the drafting of an International Bill of Rights which would have legal force in the countries that became parties to the Bill of Rights. ${ }^{12}$ However, in view of the vastly disparate social and economic conditions in U.N. member countries, the General Assembly passed a resolution which required the separation of the provisions on the more fundamental civil and political rights covenant from the more secondary provisions on economic, social and cultural rights. ${ }^{13}$

On December 16,1966, the Economic and Social Council submitted two draft covenants on fundamental human rights to the General Assembly for adoption. The covenants were titled 'The International Covenant on Civil and Political Rights' and 'The International Covenant on Economic, Social, and Cultural Rights'. Annexed to the two covenants was an Optional Protocol to the Civil and Political Rights Covenant which permits individual petitions alleging human rights violations to the U.N. Human Rights Committee. ${ }^{14}$

7. See "United Nations Action in the Field of Human Rights", U.N. Pub. ST/HR/2, Sales No. E74V. See also Egon Schwelb. "The Influence of the Universal Declaration of Human Rights on International and National Law" (1959) Am. Soc. Int. Law 217.

8. The Consultative Assembly of the Council of Europe requested that the Committee of Ministers of the same council in August. 1949, draw up a European Convention on Human Rights designed to secure and implement, in the member countries of the Council of Europe, the protection of fundamental rights enumerated in the Universal Declaration of Human Rights. For the history of the European Convention on Human Rights, see Robertson, "The European Convention for the Protection of Human Rights"(1950) 2 Brit. Yr. Bk. Int. Law 145.

9. For discussion on this point, see John P. Humphrey "World Revolution and Human Rights" in Human Rights, Federalism and Minorities (1970 ed. A. Gotlieb) 147.

10. Signed, San Francisco, 26 June, 1945. Entered into force 24 October, 1945.

11. For a respected jurist who was of the view that due to the United Nations Charter provisions on human rights, member countries were under a legal obligation to respect fundamental human rights, see Jessup, A Modern Law of Nations (1948) 91. For a contrary view, see Schwarzenberger, Power Politics (1951) 269.

12. The General Assembly requested that the Commission on Human Rights, a body set up by the Economic and Social Council of the U.N., speedily draft a covenant on human rights that would implement the protection of fundamental rights set out in the Universal Declaration of Human Rights. See G.A. Resol 217/A(iii), U.N. Doc. A/810.

13. G.A. Resol 543 (vi) Feb. 14, 1952, U.N. Doc. A/2112.

14. For the text of the two International Covenants and the Optional Protocol, see appendices I and II. 
The Civil and Political Rights Covenant is concerned with fundamental democratic and legal rights, while the Economic, Social and Cultural Rights Covenant deals with economic and social rights such as the right to 'Just and favorable conditions of work' ${ }^{\prime}$ and the right of access to educational $^{16}$ and health facilities. ${ }^{17}$ The distinction between the more fundamental Civil and Political Rights Covenant and the secondary Economic, Social and Cultural Rights Covenant can be seen from the way in which each covenant is to be implemented by signatory states. Article 2 of the Economic, Social and Cultural Rights Covenant states:

1. Each State Party to the present Covenant undertakes to take steps, individually and through international assistance and cooperation especially economic and technical, to the maximum of its available resources, with a view to achieving progressively the full realization of the rights recognized in the present Covenant by all appropriate means, including particularly the adoption of legislative measures.

2. The States Parties to the present Covenant undertake to guarantee that the rights enunciated in the present Covenant will be exercised without discrimination of any kind as to race, colour, sex, language, religion, political or other opinion, national or social origin, property, birth or other status.

3. Developing countries, with due regard to human rights and their national economy, may determine to what extent they would guarantee the economic rights recognized in the present Covenant to non-nationals.

In comparison, Article 2 of the Civil and Political Rights Covenant states:

1. Each State Party to the present Covenant undertakes to respect and to ensure to all individuals within its territory and subject to its jurisdiction the rights recognized in the present Covenant, without distinction of any kind, such as race, colour, sex, language, religion, political or other opinion, national or social origin, property, birth or other status.

2. Where not already provided for by existing legislative or other measures, each State Party to the present Covenant undertakes to take the necessary steps, in accordance with its constitutional processes and with the provisions of the present Covenant, to adopt such legislative or other measures as may be necessary to give effect to the rights recognized in the present Covenant.

3. Each State Party to the present Covenant undertakes:

(a) To ensure that any person whose rights or freedoms as herein recognized are violated shall have an effective remedy, notwithstanding that the violation has been committed by persons acting in an official capacity:

(b) To ensure that any person claiming such a remedy shall have his right thereto determined by competent judicial, administrative or legislative authorities, or by any other competent authority provided for by the legal system of the State, and to develop the possibilities of judicial remedy:

(c) To ensure that the competent authorities shall enforce such remedies when granted.

The difference in wording clearly illustrates the greater need for uniform implementation of the democratic and legal rights formulated in the Civil and Political Rights Covenant. In the remainder of the discussion in this work, only the Civil and Political Rights Covenant, which at the end of 1980 had received 67 ratifications, shall be dealt with. ${ }^{18}$

\section{CANADA ON TRIAL AT THE U.N: THE LOVELACE DECISION AND THE PROTECTION OF MINORITY RIGHTS WITHIN THE 'CANADIAN MOSAIC'}

States which have ratified the Optional Protocol to the International Covenant on Civil and Political Rights recognize the jurisdiction of the

15. Article 7 of the Covenant; for text, see Appendix I.

16. Article 13 of the Covenant; for text, see Appendix I.

17. Article 12 of the Covenant; for text, see Appendix I.

18. For the state of ratification of the Covenant, see (1980) 1 Human Rights L. J. 136 at 142 , 151 (f. 50) and 152 (f. 55). 
U.N. Human Rights Committee to receive individual communications alleging violations of rights protected by the covenant. ${ }^{19}$ When a complaint is received, the Human Rights Committees makes an investigation and then sends its findings to the country involved in the complaint. The sanction behind a finding of a violation of the Covenant by the Human Rights Committee is chiefly adverse world opinion and pressure.$^{20} \mathrm{At}$ the end of 1980, 26 states had recognized the competence of the U.N. Human Rights Committee to consider communications from individuals under the provisions of the Optional Protocol. ${ }^{21}$

Canada ratified both covenants and the Optional Protocol on May 18, $1976 .{ }^{22}$ On July 30, 1981, the Human Rights Committee, pursuant to its powers under Article 5(4) of the Optional Protocol, found Canada in breach of Article 27 of the International Covenant on Civil and Political Rights in the Sandra Lovelace case. ${ }^{23}$

Ms. Lovelace had lost her rights and status as an Indian under s.12(1)(b) of the Indian Act after marrying a non-Indian. ${ }^{24}$ Among the rights Ms. Lovelace had lost was the right to live on her band's reserve and to have access to federal government aid for Indian people in areas such as education, housing and social assistance. ${ }^{25}$ However, although Ms. Lovelace was no longer an Indian under the Indian Act, she enjoyed the same rights and privileges as any other individual in Canada and in the province in which she resided.

The Human Rights Committee observed that Ms. Lovelace's most significant claim was as follows: ${ }^{26}$

the major loss to a person ceasing to be an Indian is the loss of the cultural benefits of living in an Indian community, the emotional ties to the home, family, friends and neighbours, and the loss of identity.

Therefore, the task before the Committee was to consider whether there was a breach of Article 27 of the International Covenant on Civil and Political Rights because Ms. Lovelace was denied the legal right to reside on her reserve. Article 27 of the Covenant states:

In those states in which ethnic, religious or linguistic minorities exist, persons belonging to such a minority shall not be denied the right, in community with the other members of their group, to enjoy their own culture, to profess and practise their own religion, or to use their own language.

19. Article 1 of the Optional Protocol.

20. If the Committee finds that a country is in violation, Article $5(4)$ only permits the Com. mittee to 'forward its views to the State Party concerned and to the individual'.

21. In addition, under Article 41 of the Covenant on Civil and Political Rights, at the end of 1980. 14 states had made a declaration allowing the U.N. Human Rights Committee to consider inter-state communications. However, at the end of 1980 , no state had made such a communication.

22. Privy Council Order No. 179-1156.

23. Communication No. R 6/24. The decision of the Committee is reprinted in (1981) 2 Human Rights L. J. 158.

24. Section 12(1)b of the Indian Act, R.S.C. 1970, c. I-6 states:

(1) The following persons are not entitled to be registered, [i.e. as a status Indian] namely

(b) A woman who married a person who is not an Indian, unless that woman is subsequently the wife or widow of a person described in Section 11 [i.e. a person en. titled to be registered as a status Indian].

25. The injustice of the situation Ms. Lovelace in which found herself was highlighted by the fact that she divorced her non-Indian husband and returned to live on the Tobique Indian Reserve with her children because she had no other place to reside. But once she had married a non-Indian, she had irrevocably given up her Indian status and rights attached to such status.

26. (1981) 2 Human Rights L. J. 165. 
The Committee held that Ms. Lovelace remained a member of an ethnic minority, namely a Maliseet Indian, depite the provisions of the Indian Act which had purported to remove her Indian status. Therefore s.12(1)(b) of the Indian Act interfered with her right to access to her native culture and language in community with other members of her ethnic group.

The Committee recognized that national governments have the right to limit rights to residence, inter alia, to protect national security, public order, public health or morals or the rights and freedoms of others. More specifically, the Committee recognized that governments may have the right to limit residence on reserve land to protect the resources and identity of the particular Indian people. But, the Committee insisted that while governments should be given some latitude to limit the rights set out in Article 27, such rights have to have "both a reasonable and objective justification and be consistent with the other provisions of the Covenant read as a whole". Therefore, the Committee held that the rights in Article 27 must be construed and applied in light of other relevant provisions such as the right to freedom of movement in Article $12,{ }^{27}$ the right to privacy and family life in Article $17,,^{28}$ the prohibition against discrimination on the grounds of race, sex, etc., in Articles $2^{29}$ and $3^{30}$ and the requirement of equal protection of the law set out in Article $26{ }^{31}$

Examining the rights in Article 27 in conjunction with the other rights in the Covenant, the Committee came to the conclusion that whatever may be the merits of the Indian Act in other respects, it was not reasonable or necessary to deny Ms. Lovelace the right to reside on the reserve to preserve the identity of the band. The Committee did not consider it necessary to find separate breaches of the other rights invoked by Ms. Lovelace. The rights set out in Article 27 were the most directly applicable and the facts of the Sandra Lovelace case disclosed a breach of Article 27 of the Covenant by Canada.

The decision of the U.N. Human Rights Committee in the Lovelace case helps to shed some light on the Canadian Charter of Rights and Freedoms in several ways. It could be argued that Canadian courts should adopt a similar approach in interpreting sections of the Charter. In deciding whether any derogation from any of the rights protected by the Charter is permissible under the general limitation provisions in Section 1, the courts should incorporate the twofold test followed by the U.N. Human Rights Committee:

(1) Does the derogation have a reasonable and objective justification in terms of governmental interests? In this sense, governmental interests means the interests of society represented through democratic government.

(2) Can the derogation be justified when it is examined in conjunction with the other provisions of the Canadian Charter of Rights read as a whole?

Apart from the method of interpretation of the Covenant followed by the U.N. Human Rights Committee, the substantive issues raised by the Sandra Lovelace case beg certain questions about how the 'Canadian Mosiac' may be protected by the provisions of the Charter of Rights.

27. For text of this article, see appendix I.

28. For text of this article, see appendix I.

29. For text of this article, see appendix $I$.

30. For text of this article, see appendix I.

31. For text of this article, see appendix I. 
On January 12,1981, the Minister of Justice, Jean Chretien, appeared before the special joint committee of the Senate and the House of Commons which was examining the "Proposed Resolutions for a Joint Address to Her Majesty the Queen respecting the Constitution of Canada". During the course of his presentation, which set out various changes to the proposed resolution, Mr. Chretien made the following statement: ${ }^{32}$

Having mentioned the International Covenant [i.e. the Civil and Political Rights Covenant] I want to make one point to correct a misinterpretation that is widespread. The fact that the Charter does not entrench every provision of the Covenant does not mean that Canada is violating it. The Covenant merely requires states to protect or not violate certain rights. It does not require these rights to be entrenched in the constitution.

Attention should be paid to this statement because it reinforces the argument that just because the right set out in Article 27 of the Covenant on Civil and Political Rights are not expressly included in the Canadian Charter of Rights does not mean that ethnic, linguistic or religious minority rights can be infringed by governments in Canada.

It could be argued that the Canadian Charter of Rights does protect such rights. First, as regards the minority rights of Native peoples in Canada, such as the right to reside on the reserve and live in community with members of the band, it could be argued that $s s .25^{33}$ and $35^{34}$ of the Constitution Act $1982,{ }^{35}$ read together, entrench such rights. But ss. 25 and 35 must be read in conjunction with s. 15 (when it becomes operative) which, inter alia, requires the equal protection and equal benefit of the law and prohibits discrimination on the grounds of sex ${ }^{36}$ Therefore, a Canadian court could strike down s. 12(1)(b) of the Indian Act as being in violation of the Charter, on grounds not too dissimilar to those laid down by the U.N. Human Rights Committee in the Sandra Lovelace case.

Second, as regards other ethnic, lingustic or religious minorities existing within the 'Canadian Mosiac', it could be argued that s. 27 of the Canadian Charter puts a positive burden on the courts to interpret the provisions in the Charter in such a way as to enhance ethnic, linguistic and religious minority rights.

Third, religious minorities will be afforded protection by the freedom of religion and association provisions in $s .2^{37}$ of the Canadian Charter.

32. Minutes of Proceedings and Evidence of the Special Joint Committee of the Senate and of the House of Commons on the Constitution of Canada. A ppearance by the Honourable Jean Chretien, Minister of Justice and Attorney-General of Canada, Issue No. 36, January 12, 1981.

33. See appendix III for text of s. 25.

34. See appendix III for text of s. 35 .

35. The resolution for a Joint Address to Queen Elizabeth II respecting the constitution of Canada, was divided into seven parts, with a total of sixty sections. Part I, encompassing sections 1 to 34, constitutes the Canadian Charter of Rights and Freedoms (abbreviated to 'the Charter' or 'the Charter of Rights' in this article). Part II, comprising Section 35, is titled 'Rights of the A boriginal Peoples of Canada' and is included in the appendix to this article. Parts I to VII, comprising the Joint Address, is titled The Constitution Act, 1982. Section 52 and the Schedule to the Constitution Act, 1982 stipulates what other constitutional acts are included in the Constitution of Canada.

36. For text of s. 15, see appendix III. However, under the provisions of s. 32(2) of the Constitution Act, 1982, s. 15 will come into effect three years from April 17, 1982, the date when the Constitution Act, 1982 was assented to and proclaimed in effect by Queen Elizabeth II.

37. For text of this section, see appendix III. 
Finally, the protection in s. 15(1) of the Charter (prohibiting discrimination on the grounds of race, national or ethnic origin, colour and religion) when read together with ss. 27 and 2 of the Charter, shall provide as much protection for minorities within the 'Canadian Mosiac' as Article 27 of the Civil and Political Rights Covenant would provide, if implemented in Canada.

\section{APPLYING INTERNATIONAL JURISPRUDENCE ON THE PROTECTION OF FUNDAMENTAL RIGHTS TO THE INTERPRETATION OF THE CANADIAN CHARTER OF RIGHTS}

There is a strong argument to be made that Canadian courts should take notice of the provisions of the International Covenant on Civil and Political Rights and the decisions of the U.N. Human Rights Committee interpreting the Covenant. Such judicial notice should be taken on the basis of the canon of construction, which has been used by the Supreme Court of Canada ${ }^{38}$ that domestic courts should interpret domestic legislation in such a way as to conform to Canada's international treaty obligations and the general principles of international law. The rationale for this canon of construction is that Parliament, be it the U.K. Parliament, the Canadian Parliament or the provincial legislatures, does not intend to legislate in violation of binding treaty law or the customary rules of international law without express words to the contrary or an unambiguous and conclusive intention to violate such obligations. ${ }^{39}$

Therefore, as the Minister of Justice Jean Chretien implied, the Parliament of Canada, in sending the Constitution resolution to the United Kingdom for passage in Parliament and the Royal Assent, did not intend to violate any of Canada's international legal obligations through any of the provisions in the Canadian Charter of Rights. The Canadian courts, when interpreting the Charter, should keep these principles of statutory construction in mind.

As regards the weight Canadian courts should attach to interpretations of treaties (which Canada has ratified) by international judicial bodies, notice should be paid to Article 31(1) and (3) of the Vienna Convention on the Law of Treaties ${ }^{40}$ to which Canada has also acceded. ${ }^{41}$

Article 31(1) and (3) states:

(1) A treaty shall be interpreted in good faith in accordance with the ordinary meaning to be given to the terms of the treaty in their context and in the light of its objects and purpose.

(3) There should be taken into account, together with the context:

(a) Any subsequent agreement between the parties regarding the interpretation of the treaty or the application of its provisions:

38. See Daniels v. White and the Queen [1968] S.C.R. 517 at 541.

39. For discussion on the relationship between Canada's international legal obligations and domestic Canadian law, see MacDonald, "The Relationship between International Law and Domestic Law in Canada" in Canadian Perspectives on International Law and Organization (1974 eds. MacDonald, Morris and Johnston). It must be noted that the concomitant principle that flows from the canon of construction is that where there is a ambiguous statute (and the Canadian Charter of Rights has a lot of ambiguity in it), judicial interpretation of such a statute should be in accordance with Canada's international legal obligations, not in violation of them. See Maxwell's Interpretation of Statutes (11th ed. 1962) 142 and Salmon v. Commissioners of Customs and Excise [1967]2 Q.B. at $347 \cdot 348$.

40. U.N. Doc. A/Cont. 39/27, May 23, 1969.

41. Ratification by Canada was effected on October 14, 1970, pursuant to Privy Council Order No. 1970-1339. 
Under the Optional Protocol to the International Covenant on Civil and Political Rights, Canada and other parties who ratified the Protocol have agreed that the U.N. Human Rights Committee would interpret the treaty or, at the very least, apply its provisions to determine whether individual communications disclose violations of the Covenant. Therefore, the decisions of the U.N. Human Rights Committee, in interpreting rights similar to those in the Canadian Charter of Rights, should be regarded at least as persuasive by Canadian courts.

It is submitted that Canadian courts should pay special attention to how the U.N. Human Rights Committee deals with the limitation clauses in the Civil and Political Rights Covenant which permit governments to derogate from particular rights if certain criteria are satisfied. The Canadian people and legislatures decided to follow a similar path by inserting the general limitation clause in s. 1 of the Canadian Charter of Rights, which states:

The Canadian Charter of Rights and Freedoms guarantees the rights and freedoms set out in it subject only to such reasonable limits as can be demonstrably justified in a free and democratic society.

In contrast, the American Bill of Rights declares the entrenchment of fundamental civil and political rights in absolute terms. ${ }^{42}$ Over the centuries, the American judiciary developed limitations on these rights, balancing governmental interests against fundamental freedoms, to achieve justifiable societal goals. ${ }^{43}$ Many of the present judge-made limitations on the rights stated in the American Bill of Rights were a result of the philosophical and the political make-up of the judges who sat on the U.S. Supreme Court. Moreover, it could be argued that many of the judge-made limitations, or the lack thereof, reflected the values of American society, such as the abhorrence of prior restraints on the freedom of the press and other types of expression ${ }^{44}$ and the supreme value placed on protection of private property in all its forms. ${ }^{45}$

The Canadian people and their legislators opted for a Charter of Rights which is similar to the Universal Declaration of Human Rights, the International Covenant on Civil and Political Rights and the European Convention of Human Rights and Fundamental Freedoms. All those fundamental rights Charters have express limitations on the rights enumerated therein ${ }^{46}$ These express limitations reflect the philosophy of the drafters that certain rights can be subject to "reasonable limits prescribed by law as can be demonstrably justified in a free and democratic society". Such limitations, although drafted in an extremely vague fashion, reflect the philosophy of the people and their representatives, not that of an indepen-

42. For example, in Article 1 it states "Congress shall make no law respecting an establishment of religion, or prohibiting the free exercise thereof; or abridging the freedom of speech, or of the press; or the right of the people peaceably to assemble, and to petition the Government for a redress of grievances."

43. For an outstanding discussion of how U.S. courts have attempted to reconcile legitimate societal and governmental interests with individual freedoms, see J.E. Nowak, R.D. Rotunda and J.N. Young, Constitutional Law, (1978), Chs. $12 \cdot 19$.

44. Id.

45. For a discussion of how the U.S. courts have reconciled the taking of property interests under the principle of eminent domain with the property rights protected under the 14th Amendment, see n. 43 supra at $\mathbf{4 3 7}-450$.

46. See appendices I and III for the text of the various limitation clauses. See also, R. Hig. gins, "Derogations under Human Rights Treaties" (1978) 48 Brit. Yr. Bk. Int. Law 281. 
dent judiciary struggling to determine when governmental interests should take priority to individual freedoms and vice versa.

Therefore it could be argued that the jurisprudence arising from the International Covenant on Civil and Political Rights and the European Convention on Human Rights and Fundamental Freedoms may be of more relevance in interpreting the Canadian Charter of Rights than American jurisprudence arising from the American Bill of Rights. Because the general limitation clause in s. 1 of the Charter is so vague, Canadian courts will still have to engage in the task of balancing governmental interests against individual freedoms in deciding which should take precedence in any given situation. However, the Canadian courts have a base from which to start this process, chiefly the provisions in s. 1 of the Charter. The American courts had no such base from which to develop limitations on the rights enumerated in the American Bill of Rights. While Canadian courts should take notice of how the American judiciary developed limitations on the enumerated rights, notice should also be given to how international tribunals have interpreted express limitation clauses in the international human rights documents discussed above.

\section{THE EUROPEAN CONVENTION ON HUMAN RIGHTS}

The origins of the European Convention on Human Rights can be found in the Council of Europe which directly sponsored and created the European Convention. ${ }^{47}$ The Convention came into force on September 3,1953, and at present, twenty-one European states have ratified the convention ${ }^{48}$ Sixteen European states have made a declaration under Article $25^{49}$ of the Convention permitting individuals to petition the European Commission of Human Rights alleging violations of the Convention by member states. Seventeen countries have recognized the compulsory jurisdiction of the European Court of Human Rights. ${ }^{50}$

Article 24 of the European Convention provides for inter-state complaints. ${ }^{51}$ There have been very few of these, however, one of the most notable being the Republic of Ireland's complaint against the United Kingdom. ${ }^{52}$

47. Following the congress of Europe at the Hague in 1948, the Council of Europe [U.K. Cmd. 778, (1950) U.K. Treaty Series No. 51,(1949)] was set up on May 5, 1949. The Council was made up of a Consulative Assembly and a Committee of Ministers and had as its chief aim the promotion of European unity through, inter alia, common action in cultural, social and economic development. A high priority was given to the promotion of human rights and fundamental freedoms (Article 1. Statute of Council of Europe), and respect for such rights was a precondition for membership in the Council (Articles 3 and 8 of the Statute of the Council of Europe). For a history of how the Council of Europe nurtured and created the European Convention for the Protection of Human Rights and Fundamental Freedoms, see Robertson, supra n. 8.

48. Austria, Belgium, Cyprus, Denmark, France, Greece, Iceland, Ireland, Italy, Liechten. stein, Luxembourg, Malta, Netherlands, Norway, Portugal, Spain, Sweden, Switzerland, Turkey, United Kingdom and West Germany.

49. See appendix II for the text of Article 25. The states who have made the declaration are Austria, Belgium, Denmark, France, Iceland, Ireland, Italy, Luxembourg, Netherlands, Norway, Portugal, Sweden, Switzerland, United Kingdom and West Germany.

50. Under Article 46 of the Convention. See appendix II for the text. The states making the declaration are Austria, Belgium, Denmark, France, Greece, Iceland, Ireland, Italy, Luxembourg, Netherlands, Norway, Portugal, Spain, Sweden, Switzerland, United Kingdom and West Germany.

51. See appendix II for the text of Article 24.

52. The decision can be found in (1978) 17 Int. Leg. Mats. 160. 
It must be emphasized that these Western European countries who have acceded to the Convention, with the exception of on $e^{53}$ or two, have democratic traditions that are equal to if not greater than those of Canada and even the United States. Included among the member countries is the birthplace of democracy, Greece, and the mother of all parliamentary and common law systems, the United Kingdom.

The procedure under the European Convention to be followed when individuals allege violations of the Charter can be divided into four stages.

In the preliminary stage, the European Commission of Human Rights considers the admissibility of the complaints. ${ }^{54}$ Complainants have to exhaust their local remedies ${ }^{55}$ and prove a prima facie case. The vast majority of complaints are dismissed by the Commission as being inadmissible in that there is not enough evidence to prove a prima facie violation of the Convention ${ }^{56}$ In Canada, it is possible that at some stage in the future, our provincial courts which will no doubt handle the majority of actions or defences based on the Canadian Charter of Rights could act as a filter in a similar fashion to the European Commission of Human Rights.

The second stage in the procedure under the European Convention is set out in Articles $28-30^{57}$ which provide that where the Commission accepts the complaint as admissible, the Commission begins an investigation of the facts. This is usually a lengthy process. An attempt is also made to reach a friendly settlement, but this infrequently succeeds.

In the third stage, if a solution is not reached, the Commission, under the provisions of Article $31,{ }^{58}$ will draw up a report on the facts and state whether there has been a violation of the Convention and give reasons. This report is submitted to the Committee of Ministers of the Council of Europe who usually accept the findings of the Human Rights Commission.

At the fourth stage, two situations can arise. First, the Commission or the Government involved does nothing. If this happens, the Committee of Ministers may decide to publish the Commission's report and will discuss what further remedial steps may be taken.$^{59}$ Second, within three months of the Commission transmitting its report to the Committee of Ministers, the Commission may refer the matter to the European Court of Human Rights, set up under Article 38 of the Convention. ${ }^{60}$ The state against whom the complaint has been lodged or whose national is alleged to be a victim, can also refer the complaint to the European Court of Human Rights. ${ }^{61}$ Once the matter is referred to the court, the decision of the court is final and binding on all the parties involved under Article 53 of the Convention. ${ }^{62}$ The Committee of Ministers under Article 54 supervises the execution of the Judgment of the European Court of Human Rightș. ${ }^{63}$

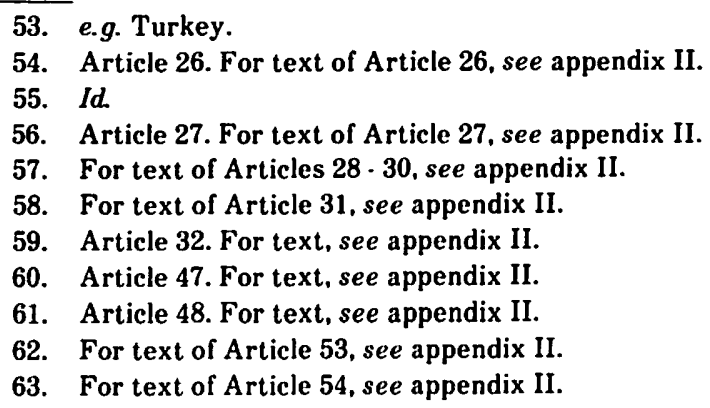


V. THE EUROPEAN EXPERIENCE IN THE LAW AND PRACTICE OF FUNDAMENTAL RIGHTS; THE DOCTRINE OF THE GOVERNMENTAL 'MARGIN OF APPRECIATION'

It is beyond the scope of this work to discuss how the European Commission of Human Rights and the European Court of Human Rights have interpreted the various provisions of the European Convention of Human Rights. ${ }^{64}$ Rather, this part of the work shall concentrate on a "thread" of jurisprudence developed by the European Court in its interpretation of the European Convention in the belief that there are vital lessons to be learned by the Canadian courts from this study.

In Ireland v. U.K. ${ }^{65}$ the Republic of Ireland made two complaints against the U.K. One of the complaints was subsequently withdrawn, but the other complaint resulted in a hearing by the European Court. The Republic of Ireland alleged violations by the U.K. of Articles 1, 3, 5, 6 and 14 of the Convention. ${ }^{66}$

The Irish complaint concerned the policy of internment and detention of I.R.A. personnel in Northern Ireland between 1971 and 1975. Pursuant to powers given under regulations made under the Civil Authorities (Special Powers) Act, N.I. 1922, British officials began to intern individuals suspected of terrorist activities, even though there may not have been sufficient evidence to bring such individuals to trial. Hundreds of individuals were interned without trial. The Republic of Ireland picked sixteen "illustrative cases" and claimed that the internees had been subjected to five techniques ${ }^{67}$ of interrogation that amounted to "torture or inhuman or degrading treatment or punishment," in violation of Article 3 of the European Convention.

The Commission found that the use of the 'five techniques' amounted to a practice of torture contrary to Article 3. However, the European Court of Human Rights disagreed that the practice amounted to torture, but held that the 'five techniques' constituted an 'administrative practice' involving 'inhuman treatment' contrary to Article 3 . The prohibitions set out in Article 3 could not be derogated from, even in times of public emergencies.

Regarding the allegations based on other provisions of the European Convention, the Court held that although internment without trial was contrary to Articles 5 and 6 of the European Convention, there was no breach of Convention because a public emergency existed in Northern Ireland which threatened the life of the nation. This threat permitted derogations by the U.K. Government under Article 15, and the measures which the U.K. Government had taken were properly notified and were strictly proportionate to control the public emergency.

64. For works discussing the interpretation of the provisions of the European Convention, see F. Jacobs, The European Convention of Human Rights (1975); J. Fawcett, The Application of the European Convention on Human Rights (1969); A. Robertson, Human Rights in Europe (1977).

65. Supra n. 52.

66. For text of these articles, see appendix II.

67. The 'five techniques' were:

(1) Standing 'spreadeagled' against the wall.

(2) Hooding of detainees.

(3) Subjugation to a loud and continuous 'hissing' noise.

(4) Deprivation of sleep pending interrogation.

(5) Deprivation or reduction of food and drink. 
The basic issues before the court in this regard were who would decide when a public emergency existed which would justify derogation from some of the Convention rights, and whether the decision to declare a public emergency could later be questioned by the European Court of Human Rights. Addressing these issues, the Court stated: ${ }^{88}$

207. The limits on the Court's powers of review ... are particularly apparent where Article 15 is concerned.

It falls in the first place to each Contracting State, with its repsonsibility for "the life of [its] nation", to determine whether that life is threatened by a "public emergency" and, if so, how far it is necessary to go in attempting to overcome the emergency. By reason of their direct and continuous contact with the pressing needs of the moment, the national authorities are in principle in a better position than the international judge to decide both on the presence of such an emergency and on the nature and scope of derogations necessary to avert it. In this matter Article 15(1) leaves those authorities a wide margin of appreciation.

Nevertheless, the States do not enjoy an unlimited power in this respect. The Court, which, with the Commission, is responsible for ensuring the observance of the States' engagements (Article $19)$, is empowered to rule on whether the States have gone beyond the "extent strictly required by the exigencies" of the crisis ....

The domestic margin of appreciation is thus accompanied by a European supervision.

214. The Irish Government submit that experience shows extrajudicial deprivation of liberty to have been ineffectual. They contend that the policy introduced on 9 A ugust 1971 not only failed to put a brake on terrorism but also had the result of increasing it .... Consequently, the British Government, after attenuating the policy in varying degrees following the introduction of direct rule ... abandoned it on 5 December 1975: since then, it appears that no one has been detained in the six counties under the emergency legislation, despite the persistence of an intense campaign of violence and even though the Emergency Provisions Amendment Act has remained in force... . This, claim the applicant Government, confirms that extrajudicial deprivation of liberty was not an absolute necessity.

The Court cannot accept this argument.

It is certainly not the Court's function to substitute for the British Government's assessment any other assessment of what might be the most prudent or most expedient policy to combat terrorism. The Court must do no more than review the lawfulness, under the Convention, of the measures adopted by that Government from 9 August 1971 onwards. For this purpose the Court must arrive at its decision in the light, not of a purely retrospective examination of the efficacy of those measures, but of the conditions and circumstances reigning when they were originally taken and subsequently applied.

Adopting, as it must, this approach, the Court accepts that the limits of the margin of appreciation left to the Contracting States by Article 15 (1) were not overstepped by the United Kingdom when it formed the opinion that extrajudicial deprivation of liberty was necessary from August 1971 to March 1975.

220. An overall examination of the legislation and practice at issue reveals that they evolved in the direction of increasing respect for individual liberty. The incorporation right from the start of more satisfactory judicial, or at least administrative, guarantees would certainly have been desirable, especially as Regulations 10 to 12(1) dated back to 1956-1957 and were made under an Act of 1922, but it would be unrealistic to isolate the first from the later phases. When a State is struggling against a public emergency threatening the life of the nation, it would be rendered defenceless if it were required to accomplish everything at once, to furnish from the outset each of its chosen means of action with each of the safeguards reconcilable with the priority requirements for the proper functioning of the authorities and for restoring peace within the community. The interpretation of Article $\mathbf{1 5}$ must leave a place for progressive adaptations.

The Northern Ireland Government sought in the first place - unsuccessfully - to meet the most pressing problem, to stem the wave of violence that was sweeping the region. After assuming direct responsibility for the future of the province, the British Government and Parliament lost little time in moderating in certain respects the severity of the laws applied in the early days. The Court asked itself whether those laws should not have been attenuated even more, especially as regards interim custody (see paragraph 217 above), but does not consider that it can given an affirmative answer. It must not be forgotten that the crisis experienced at the time by the six counties was serious and, hence, of a kind that justified far-reaching derogations from paragraphs 2 to 4 of Article 5. In view of the Contracting States' margin of appreciation, the Court does not find it established that the United Kingdom exceeded in this repsect the "extent strictly required" referred to in Article 15(1).

68. Supra n. 52 at 707 (para. 207), 708 (para. 214), 709 (para. 220). 
As other writers have pointed out, there is nothing inherently wrong in the European Court's deference to the national government's ability to judge correctly when a public emergency exists, and what measures are strictly and proportionately required to control the emergency situation. ${ }^{69}$ However the deference shown under the 'Margin of Appreciation' doctrine began to show up in decisions of the European Court not dealing with public emergency situations. The most well known decision in which the European Court of Human Rights applied the 'Margin of Appreciation' doctrine to a non-emergency situation is the Sunday Times case. $^{70}$

The facts of the case can be simplified as follows. In 1972, Distillers, the British manufacturers of the thalidomide drug, was negotiating settlements with the parents of children born deformed as a result of the ingestion of the drug by mothers during pregnancy. The Sunday Times newspaper intended to publish an article discussing the evidence on the issue of Distillers' negligence in producing the drug. The British Attorney-General obtained an injunction preventing publication of the article. The injunction was eventually upheld by a unanimous decision from the House of Lords ${ }^{71}$ who gave various reasons for their decisions. Lords Diplock and Simon held that the publication of the article would amount to contempt of court as the publication would put pressure on the parents not to abandon or settle the court actions. Lords Reid, Morris and Cross held that the publication would be contempt of court as the article would tend to prejudge the issues which were the subject of negligence actions initiated by the parents. All agreed that the publication would be in contempt of court because it threatened the proper administration of justice.

The publisher, editor, and some of the journalists of the Sunday Times brought a complaint before the European Commission of Human Rights alleging that the injunction against the Sunday Times was in breach of the freedom of expression provisions in Article 10 of the Convention. ${ }^{72}$ The European Commission of Human Rights referred the complaint to the European Court of Human Rights.

The Court held that the Sunday Times' right to freedom of expression had been violated because the restrictions imposed by the common law rules of contempt of court although 'prescribed by law'73 and serving a legitimate purpose ${ }^{74}$ were not 'necessary in a democratic society' ${ }^{75}$ to protect the 'authority of the judiciary'. ${ }^{76}$

The European Court of Human Rights discussed the meaning of the term 'prescribed by law' by stating:77

The word "law" in the expression "prescribed by law" covers not only the statute but also unwritten law. Accordingly, the Court does not attach importance here to the fact that contempt of court

69. See L.C. Green, “Derogation of Human Rights in Emergency Situations” (1978) 16 Can. Yr. Bk. Int. Law. 92, 98-100.

70. E.C.H.R. Series A Vol. 30.

71. Att.-Gen. v. Times Neuspapers $L t d$ [1974] A.C. 273 at 327; [1973] 3 All E.R. 54 at 87.

72. For text of Article 10, see appendix II.

73. See n. 76 infra.

74. Supra n. 70 at para. 54 - para. 57.

75. Id at para. 58 - para. 68.

76. Id.

77. Id at para. 47 - para. 49 . 
is a creature of the common law and not of legislation. It would clearly be contrary to the intention of the drafters of the Convention to hold that a restriction imposed by virtue of the common law is not "prescribed by law" on the sole ground that it is not enunciated in legislation: this would deprive a common-law State which is Party to the Convention of the protection of Article 10(2) and strike at the very roots of that State's legal system. In fact, the applicants do not argue that the expression "prescribed by law" necessitates legislation in every case: their submission is that legislation is required only if - as in the present case - the common-law rules are so uncertain that they do not satisfy what the applicants maintain is the concept enshrined in that expression, namely the principle of legal certainty

48. The expression "prescribed by law" appears in paragraph 2 of Articles 9,10 and 11 of the Convention, the equivalent in the French text being in each case "prevues par la loi". However, when the same French expression appears in Article 8(2) of the Convention, in Article 1 of Protocol No. 1 and in Article 2 of Protocol No. 4, it is rendered in the English text as "in accordance with the law". "provided for by law" and "in accordance with law", respectively. Thus confronted with the versions of a law-making treaty which are equally authentic but not exactly the same. the Court must interpret them in a way that reconciles them as far as possible and is most appropriate in order to realise the aim and achieve the object of the treaty ....

49. In the court's opinion, the following are two of the requirements that flow from the expression "prescribed by law". Firstly, the law must be adequately accessible: the citizen must be able to have an indication that is adequate in the circumstances of the legal rules applicable to a given case. Secondly, a norm cannot be regarded as a "law" unless it is formulated with sufficient precision to enable the citizen to regulate his conduct: he must be able - if need be with appropriate advice to foresee, to a degree that is reasonable in the circumstances, the consequences which a given action may entail. Those consequences need not be foreseeable with absolute certainty: experience shows this to be unattainable. Again, whilst certainty is highly desirable, it may bring in its train excessive rigidity and the law must be able to keep pace with changing circumstances. Accordingly, many laws are inevitably couched in terms which, to a greater or lesser extent, are vague and whose interpretation and application are questions of practice.

While it it beyond the scope of this work to analyze the court's discussion of the term 'prescribed by law', Canadian courts should pay particular attention to the discussion as the very same term, "prescribed by law', appears in the general limitation provisions in s. 1 of the Canadian Charter of Rights. Further, there is an argument to be made, based on the wording of s.1, that reinforces the thesis that the Canadian Charter of Rights must be interpreted so as to conform to Canada's international legal obligations.

The preamble to the Canadian Charter of Rights states that Canada is 'founded upon the principles that recognize the supremacy of God and the rule of law' ${ }^{78}$ Section 1 of the Canadian Charter of Rights must be interpreted to conform to the rule of law. The rule of law must of necessity include adherence to Canada's international legal obligations which no level of government in Canada can violate, at least not without express wording in legislation to the contrary. ${ }^{79}$

In this regard, Article 4(2) of the International Covenant on Civil and Political Rights, which imposes binding legal obligations on Canada, prohibits derogation from certain basic rights even in times of public emergency. ${ }^{80}$ Among these basic rights protected from derogation are the right not to be arbitrarily deprived of life ${ }^{81}$ the prohibition against torture or cruel, inhuman or degrading treatment or punishment ${ }^{82}$ and the

78. For text of preamble, see appendix II. Emphasis added.

79. For discussion on whether the federal or provincial governments can violate Canada's international legal obligations, see MacDonald, supra. n. 39; see also the recent decision of the Alberta Court of Queen's Bench in A.U.P.E. v. the Crown in Right of Alberta, unreported, 25 July 1980, J. D. of Edmonton, 8003-18095 (Alta. Q.B.), judgment of Chief Justice Sinclair.

80. For text of Article 4(2), see appendix I.

81. Article 6(1). For text of article, see appendix $I$.

82. Article 7. For text of article, see appendix I. 
right not to be convicted of an offence which was not regarded as a criminal offence under national or international law at the time the act or omission constituting the offence occurred. ${ }^{83}$ There is nothing in $\mathrm{s} .1$ or in any other provision of the Canadian Charter of Rights which prohibits expressly a government from derogating from these same basic rights (listed in Sections $7,11(\mathrm{~g})$ and $12^{84}$ of the Charter), even in times of public emergency. It is submitted that if any government in Canada were to derogate from any of these most basic rights, even in times of public emergency, such derogations would be in violation of Canada's international legal obligations. Therefore, it would be hard to justify such violations as 'demonstrably justified in a free and democratic society'.

Returning to the analysis of the European Court's decision in the Sunday Times case, the court also discussed whether the restrictions imposed on the newspaper were necessary in a democratic society. The court, adopting its own jurisprudence from the earlier Handyside ${ }^{85}$ case, stated: ${ }^{86}$

The Court has noted that, whilst the adjective "necessary" within the meaning of Article 10(2), is not synonymous with "indispensible", neither has it the flexibility of such expressions as "admissible", "ordinary", "useful", "reasonable" or "desirable" and that implies the existence of a "press. ing social need". In the second place, the Court has underlined that the initial responsibility for securing the rights and freedoms enshrined in the Convention lies with the individual Contracting States. Accordingly, Article 10(2) leaves to the Contracting States a margin of appreciation. This margin is given both to the domestic legislator .... and to the bodies, judicial amongst others, that are called upon to interpret and apply the laws in force. Nevertheless, Article 10(2) does not give the Contracting States an unlimited power of appreciation: The Court ... is empowered to give the final ruling on whether a "restriction"... is reconcilable with freedom of expression as protected by Article 10.

So in the Sunday Times case, as in the earlier Handyside case, the European Court of Human Rights extended its deference to the national government's 'Margin of Appreciation' from public emergency situations to non-emergency situations.

The 'Margin of Appreciation' doctrine was evolved by the European Court of Human Rights, a supranational court, to permit soverign states

83. Article 15. For text of article, see appendix I.

84. For text of these sections of the Canadian Charter of Rights and freedoms, see appendix III.

85. Judgment of the European Court of Human Rights, Dec. 7, 1976, Series A Vol. 24.

In the Handyside case, copies of the applicant's allegedly obscene publication, "The Little Red Schoolbook" were seized by London Police from his premises pursuant to the U.K. Obscene Publications Act 1959 and 1964. A pproximately 18,800 copies had already been sold. The applicant was also charged and convicted for having in his possession obscene articles for gain, contrary to the Obscene Publications Act. The fuss was about a 26 page section of the Book, comprising about $13 \%$ of the whole book aimed at school children and discusing such subjects as masturbation, orgasm, petting and homosexuality. The applicant claimed that his treatment by the U.K. authorities was in violation of Article 10 of the Convention. The European Court stated that the main issue in the case was whether the limitation placed on Handyside's freedom of expression was justifiable under Article 10(2) as being 'prescribed by law and... necessary in a democratic society ... for the protection of morals.' The European court held that there was no violation of Article 10 . Applying 'the margin of appreciation doctrine', the court held that state authorities were in a better position than an international judge to ascertain when the requirement of the protection of public morals was such a 'pressing social need', as to make 'necessary' a 'restriction' or 'penalty'. The Court held that the penalties imposed by the U.K. authorities on Handyside were "prescribed by law", and were "necessary in a democratic society" and "proportionate" to the legitimate aim pursued (i.e. the protection of public morals).

86. Supra. n. 70 at para. 59. 
to regulate their internal affairs as much as possible, subject only to a general European supervision. ${ }^{87}$ Therefore, it could be argued that such European jurisprudence should not be applied in interpreting the Canadian Charter of Rights, as, at least in theory, there is no collection of sovereign states in Canada, and the Supreme Court of Canada and other domestic courts are not supranational courts.

However, it is submitted that the judicial deference given to government's 'margin of appreciation' in deciding when governmental interests should take priority over individual freedoms is inherent in a fundamental rights document that has express limitations on the enumerated rights. ${ }^{88}$ Therefore it is possible that Canadian courts may give governments a 'margin of appreciation' to decide when governmental interests should take priority to the rights set out in the Canadian Charter of Rights. However, as the European court in the Sunday Times case held, there must be judicial supervision of the 'margin of appreciation' to determine whether the legitimate governmental measures taken are 'necessary'; that is, proportionate to the legitimate and pressing social objective pursued. This is a procedure which Canadian courts could follow in determining whether any legitimate governmental measures that violate any of the rights in the Charter of Rights can be 'demonstrably justified in a free and democratic society'.

\section{CONCLUSION}

The essence of what Canadian courts can learn from the U.N. and European law and practice in the area of fundamental rights can be summarized as follows.

Fundamental rights, apart from the most basic, such as the right to life and freedom from torture or cruel and unusual treatment and punishment, are not absolute. Such rights in times of public emergency or when there is a pressing social need, may have to give way to the reasonable and legitimate objectives of a free and democratic society. ${ }^{89}$ However, judicial bodies must ensure, when interpreting fundamental rights documents that expressly permit derogations from enumerated rights,

(1) The derogation is proportionate to the objective pursued and strictly necessary to achieve the legitimate societal objective.

(2) The derogation can be justified when it is examined in conjunction with the other provisions of the fundamental rights document.

87. As the European Court of Human Rights stated in the Handyside case, supra n. 86, .... it is for the national authorities to make the initial assessment of the reality of the pressing social need implied by the notion of 'necessity'." Series A Vol. 24, para. 48.

88. Under s. 1 of the Canadian Charter of Rights and Freedoms, authorities in Canada have to 'demonstrably justify' reasonable limitations. It could be argued this is another way of stating that authorities in Canada should be allowed to make the initial assessment of the reality of the pressing social need'. See n. 87 supra. If such authorities can 'demonstrably justify' such limitations as necessary, then the Canadian courts will uphold the initial 'margin of appreciation' exercised by governmental authorities in Canada.

89. The European Court of Human Rights, in the recent Closed Shop case (Application No. 7601/76) European Court of Human Rights, Law judgment of August 13, 1981, reprinted in [1981] 2 Human Rights $L$. J. 185, gave the following brief definition of a 'democratic' society:

.... pluralism, tolerance and broad-mindedness are hallmarks of a "democratic society". Although individual interests must on occasion be subordinated to those of a group, democracy does not simply mean that the views of a majority must always prevail: a balance must be achieved which ensures the fair and proper treatment of minorities and avoids any abuse of a dominant position. 
The courts may have to give the executive or legislative arm of government an initial 'margin of appreciation' to determine when the facts justify a derogation from fundamental rights and what measures are strictly necessary to achieve the legitimate societal objective.

Canadian courts should examine American jurisprudence to determine how the American judiciary over the centuries has developed limitations on the fundamental rights expressed in absolute terms in the Bill of Rights. However, it may be more appropriate for the Canadian courts to look to United Nations and especially European jurisprudence in certain areas concerning fundamental rights. Such jurisprudence should be examined particularly where it elaborates on limitation clauses and concepts, such as the concept of 'prescribed by law', which are identical to those found in the Canadian Charter of Rights and Freedoms.

\section{APPENDIX I}

\section{INTERNATIONAL COVENANT ON CIVIL AND POLITICAL RIGHTS}

\section{PREAMBLE}

The States Parties to the present Covenant,

Considering that, in accordance with the principles proclaimed in the Charter of the United Nations, recognition of the inherent dignity and of the equal and inalienable rights of all members of the human family is the foundation of freedom, justice and peace in the world,

Recognizing that these rights derive from the inherent dignity of the human person,

Recognizing that, in accordance with the Universal Declaration of Human Rights, the ideal of free human beings enjoying civil and political freedom and freedom from fear and want can only be achieved if conditions are created whereby everyone may enjoy his civil and political rights, as well as his economic, social and cultural rights,

Considering the obligation of States under the Charter of the United Nations to promote universal respect for, and observance of, human rights and freedoms,

Realizing that the individual, having duties to other individuals and to the community to which he belongs, is under a responsibility to strive for the promotion and observance of the rights recognized in the present Covenant,

Agree upon the following articles:

\section{PART I}

Article 1. - 1. All peoples have the right of self-determination. By virtue of the right they freely determine their political status and freely pursue their economic, social and cultural development.

2. All peoples may, for their own ends, freely dispose of their natural wealth and resources without prejudice to any obligations arising out of international economic co-operation, based upon the principle of mutual benefit, and international law. In no case may a people be deprived of its own means of subsistence.

3. The States Parties to the present Covenant, including those having responsibility for the administration of Non-Self-Governing and Trust Territories, shall promote the realization of the right of self- 
determination, and shall respect that right, in conformity with the provisions of the United Nations Charter.

\section{PART II}

Article 2. - 1. Each State Party to the present Covenant undertakes to respect and to ensure to all individuals within its territory and subject to its jurisdiction the rights recognized in the present Covenant, without distinction of any kind, such as race, colour, sex, language, religion, political or other opinion, national or social origin, property, birth or other status.

2. Where not already provided for by existing legislative or other measures, each State Party to the present Covenant undertakes to take the necessary steps, in accordance with its constitutional processes and with the provisions of the present Covenant, to adopt such legislative or other measures as may be necessary to give effect to the rights recognized in the present Covenant.

3. Each State Party to the present Covenant undertakes:

(a) To ensure that any person whose rights or freedoms as herein recognized are violated, shall have an effective remedy notwithstanding that the violation has been committed by persons acting in an official capacity;

(b) To ensure that any person claiming such a remedy shall have his right thereto determined by competent judicial, administrative or legislative authorities, or by any other competent authority provided for by the legal system of the State, and to develop the possibilities of judicial remedy;

(c) To ensure that the competent authorities shall enforce such remedies when granted.

Article 3. The State Parties to the present Covenant undertake to ensure the equal right of men and women to the enjoyment of all civil and political rights set forth in the present Covenant.

Article 4. - 1. In time of public emergency which threatens the life of the nation and the existence of which is officially proclaimed, the States Parties to the present Covenant may take measures derogating from their obligations under the present Covenant to the extent strictly required by the exigencies of the situation, provided that such measures are not inconsistent with their other obligations under international law and do not involve discrimination solely on the ground of race, colour, sex, language, religion or social origin.

2. No derogation from articles 6, 7, 8 (paragraphs 1 and 2), 11, 15, 16 and 18 may be made under this provision.

3. Any State Party to the present Covenant availing itself of the right of derogation shall inform immediately the other States Parties to the present Covenant, through the intermediary of the Secretary-General of the United Nations of the provisions from which it has derogated and of the reasons by which it was actuated. A further communication shall be made, through the same intermediary, on the date on which it terminates such derogation.

Article 5. - 1. Nothing in the present Covenant may be interpreted as implying for any State, group or person any right to engage in any activity or perform any act aimed at the destruction of any of the rights and freedoms recognized herein or at their limitation to a greater extent than 
is provided for in the present Covenant.

2. There shall be no restriction upon or derogation from any of the fundamental human rights recognized or existing in any State Party to the present Covenant pursuant to law, conventions, regulations or custom on the pretext that the present Covenant does not recognize such rights or that it recognized them to a lesser extent.

\section{PART III}

Article 6. -1. Every human being has the inherent right to life. This right shall be protected by law. No one shall be arbitrarily deprived of his life.

2. In countries which have not abolished the death penalty, sentence of death may be imposed only for the most serious crimes in accordance with law in force at the time of the commission of the crime and not contrary to the provisions of the present Covenant and to the Convention on the Prevention and Punishment of the Crime of Genocide. This penalty can only be carried out pursuant to a final judgment rendered by a competent court.

3. When deprivation of life constitutes the crime of genocide, it is understood that nothing in this article shall authorize any State Party to the present Covenant to derogate in any way from any obligation assumed under the provisions of the Convention on the Prevention and Punishment of the Crime of Genocide.

4. Anyone sentenced to death shall have the right to seek pardon or commutation of the sentence. Amnesty, pardon or commutation of the sentence of death may be granted in all cases.

5. Sentence of death shall not be imposed for crimes committed by persons below eighteen years of age and shall not be carried out on pregnant women.

6. Nothing in this article shall be invoked to delay or to prevent the abolition of capital punishment by any State Party to the present Covenant.

Article 7. No one shall be subjected to torture or to cruel, inhuman or degrading treatment or punishment. In particular, no one shall be subjected without his free consent to medical or scientific experimentation.

Article 8. -1 . No one shall be held in slavery; slavery and the slavetrade in all their forms shall be prohibited.

2. No one shall be held in servitude.

3. (a) No one shall be required to perform forced or compulsory labour:

(b) The preceding sub-paragraph shall not be held to preclude in countries where imprisonment with hard labour may be imposed as a punishment for a crime, the performance of hard labour in pursuance of a sentence to such punishment by a competent court;

(c) For the purpose of this paragraph the term "forced or compulsory labour" shall not include:

(i) Any work or service, not referred to in subparagraph (b), normally required of a person who is under detention in consequence of a lawful order of a court, or of a person during conditional release from such detention;

(ii) Any service of a military character and, in countries where conscientious objection is recognized, any national service required 
by law of conscientious objectors;

(iii) Any service exacted in cases of emergency or calamity threatening the life or well-being of the community;

(iv) Any work or service which forms part of normal civil obligations.

Article 9. -1. Everyone has the right to liberty and security of person. No one shall be subjected to arbitrary arrest or detention. No one shall be deprived of his liberty except on such grounds and in accordance with such procedures as are established by law.

2. Anyone who is arrested shall be informed, at the time of arrest, of the reasons for his arrest and shall be promptly informed of any charges against him.

3. Anyone arrested or detained on a criminal charge shall be brought promptly before a judge or other officer authorized by law to exercise judicial power and shall be entitled to trial within a reasonable time or to release. It shall not be the general rule that persons awaiting trial shall be detained in custody, but release may be subject to guarantees to appear for trial, at any other stage of the judicial proceedings, and, should occasion arise, for execution of the judgment.

4. Anyone who is deprived of his liberty by arrest or detention shall be entitled to take proceedings before a court, in order that such court may decide without delay on the lawfulness of his detention and order his release if the detention is not lawful.

5. Anyone who has been the victim of unlawful arrest or detention shall have an enforceable right to compensation.

Article 10. - 1. All persons deprived of their liberty shall be treated with humanity and with respect for the inherent dignity of the human person.

2. (a) Accused persons shall, save in exceptional circumstances, be segregated from convicted persons, and shall be subject to separate treatment appropriate to their status as unconvicted persons;

(b) Accused juvenile persons shall be separated from adults and brought as speedily as possible for adjudication.

3 . The penitentiary system shall comprise treatment of prisoners the essential aim of which shall be their reformation and social rehabilitation. Juvenile offenders shall be segregated from adults and be accorded treatment appropriate to their age and legal status.

Article 11. No one shall be imprisoned merely on the ground of inability to fulfil a contractual obligation.

Article 12.-1. Everyone lawfully within the territory of a State shall, within that territory, have the right to liberty of movement and freedom to choose his residence.

2. Everyone shall be free to leave any country, including his own.

3. The above-mentioned rights shall not be subject to any restrictions except those which are provided by law, are necessary to protect national security, public order ("ordre public"), public health or morals or the rights and freedoms of others, and are consistent with the other rights recognized in the present Covenant.

4. No one shall be arbitrarily deprived of the right to enter his own country.

Article 13. An alien lawfully in the territory of a State Party to the present Covenant may be expelled therefrom only in pursuance of a deci- 
sion reached in accordance with law and shall, except where compelling reasons of national security otherwise require, be allowed to submit the reasons against his expulsion and to have his case reviewed by, and be represented for the purpose before, the competent authority or a person or persons especially designated by the competent authority.

Article 14. - 1. All persons shall be equal before the courts and tribunals. In the determination of any criminal charge against him, or of his rights and obligations in a suit at law, everyone shall be entitled to a fair and public hearing by a competent, independent and impartial tribunal established by law. The Press and the public may be excluded from all or part of a trial for reasons of morals, public order ("ordre public") or national security in a democratic society, or when the interest of the private lives of the parties so requires, or to the extent strictly necessary in the opinion of the court in special circumstances where publicity would prejudice the interests of justice; but any judgment rendered in a criminal case or in a suit at law shall be made public except where the interest of juveniles otherwise requires or the proceedings concern matrimonial disputes or the guardianship of children.

2. Everyone charged with a criminal offence shall have the right to be presumed innocent until proved guilty according to law.

3. In the determination of any criminal charge against him, everyone shall be entitled to the following minimum guarantees, in full equality:

(a) To be informed promptly and in detail in a language which he understands of the nature and cause of the charge against him;

(b) To have adequate time and facilities for the preparation of his defence and to communicate with counsel of his own choosing;

(c) To be tried without undue delay;

(d) To be tried in his presence, and to defend himself in person or through legal assistance of his own choosing; to be informed, if he does not have legal assistance, of this right; and to have legal assistance assigned to him, in any case where the interests of justice so require, and without payment by him in any such case if he does not have sufficient means to pay for it;

(e) To examine, or have examined, the witnesses against him and to obtain the attendance and examination of witnesses on his behalf under the same conditions as witness against him;

(f) To have the free assistance of an interpreter if he cannot understand or speak the language used in court;

(g) Not to be compelled to testify against himself, or to confess guilt.

4. In the case of juveniles, the procedure shall be such as will take account of their age and the desirability of promoting their rehabilitation.

5. Everyone convicted of a crime shall have the right to his conviction and sentence being reviewed by a higher tribunal according to law.

6. When a person has by a final decision been convicted of a criminal offence and when subsequently his conviction has been reversed or he has been pardoned on the ground that a new or newly discovered fact shows conclusively that there has been a miscarriage of justice, the person who has suffered punishment as a result of such conviction shall be compensated according to law, unless it is proved that the non-disclosure of the unknown fact in time is wholly or partly attributable to him.

7. No one shall be liable to be tried or punished again for an offence for which he has already been finally convicted or acquitted in accordance 
with the law and penal procedure of each country.

Article 15. - 1. No one shall be held guilty of any criminal offence on account of any act or omission which did not constitute a criminal offence, under national or international law, at the time when it was committed. Nor shall a heavier penalty be imposed than the one that was applicable at the time when the criminal offence was committed. If, subsequently to the commission of the offence, provision is made by law for the imposition of a lighter penalty, the offender shall benefit thereby.

2. Nothing in this article shall prejudice the trial and punishment of any person for any act or omission which, at the time when it was committed, was criminal according to the general principles of law recognized by the community of nations.

Article 16. Everyone shall have the right to recognition everywhere as a person before the law.

Article 17. - 1. No one shall be subjected to arbitrary or unlawful interference with his privacy, family, home or correspondence, nor to unlawful attacks on his honour and reputation.

2. Everyone has the right to the protection of the law against such interference or attacks.

Article 18. - 1. Everyone shall have the right to freedom of thought, conscience and religion. This right shall include freedom to have or to adopt a religion or belief of his choice, and freedom either individually or in community with others and in public or private, to manifest his religion or belief in worship, observance, practice and teaching.

2. No one shall be subject to coercion which would impair his freedom to have or to adopt a religion or belief of his choice.

3. Freedom to manifest one's religion or beliefs may be subject only to such limitations as are prescribed by law and are necessary to protect public safety, order, health, or morals or the fundamental rights and freedoms of others.

4. The States Parties to the present Covenant undertake to have respect for the liberty of parents and, when applicable, legal guardians, to ensure the religious and moral education of their children in conformity with their own convictions.

Article 19.-1. Everyone shall have the right to hold opinions without interference.

2. Everyone shall have the right to freedom of expression; this right shall include freedom to seek, receive and impart information and ideas of all kinds, regardless of frontiers, either orally, in writing or in print, in the form of art, or through any other media of his choice.

3 . The exercise of the rights provided for in the foregoing paragraph carries with it special duties and responsibilities. It may therefore be subject to certain restrictions, but these shall be such only as are provided by law and are necessary, (1) for respect of the rights or reputations of others, (2) for the protection of national security or of public order ("ordre public"), or of public health or morals.

Article 20. - 1. Any propaganda for war shall be prohibited by law.

2. Any advocacy of national, racial, or religious hatred that constitutes incitement to discrimination, hostility or violence shall be prohibited by law.

Article 21. The right of peaceful assembly shall be recognized. No restrictions may be placed on the exercise of this right other than those 
imposed in conformity with the law and which are necessary in a democratic society in the interests of national security or public safety, public order ("ordre public"), the protection of public health or morals or the protection of the rights and freedoms of others.

Article 22. - 1. Everyone shall have the right to freedom of association with others, including the right to form and join trade unions for the protection of his interests.

2. No restrictions may be placed on the exercise of this right other than those prescribed by law and which are necessary in a democratic society in the interests of national security or public safety, public order ("ordre public"), the protection of public health or morals or the protection of the rights and freedoms of others. This article shall not prevent the imposition of lawful restrictions on members of the armed forces and of the police in their exercise of this right.

3. Nothing in this article shall authorize States Parties to the International Labour Convention of 1948 on Freedom of Association and Protection of the Right to Organize to take legislative measures which would prejudice, or to apply the law in such a manner as to prejudice, the guarantees provided for in the Convention.

Article 23. - 1. The family is the natural and fundamental group unit of society and is entitled to protection by society and the State.

2. The right of men and women of marriageable age to marry and to found a family shall be recognized.

3. No marriage shall be entered into without the free and full consent of the intending spouses.

4. States Parties to the present Covenant shall take appropriate steps to ensure equality of rights and responsibilities of spouses as to marriage, during marriage and at its dissolution. In the case of dissolution, provision shall be made for the necessary protection of any children.

Article 24. - 1. Every child shall have, without any discrimination as to race, colour, sex, language, religion, national or social origin, property or birth, the right to such measures of protection as required by his status as a minor, on the part of his family, the society and the State.

2. Every child shall be registered immediately after birth and shall have a name.

3. Every child has the right to acquire a nationality.

Article 25. Every citizen shall have the right and the opportunity, without any of the distinctions mentioned in article 2 and without unreasonable restrictions:

(a) To take part in the conduct of public affairs, directly or through freely chosen representatives;

(b) To vote and to be elected at genuine periodic elections which shall be by universal and equal suffrage and shall be held by secret ballot, guaranteeing the free expression of the will of the electors;

(c) To have access, on general terms of equality, to public service in his country.

Article 26. All persons are equal before the law and are entitled without any discrimination to equal protection of the law. In this respect the law shall prohibit any discrimination and guarantee to all persons equal and effective protection against discrmination on any ground such as race, colour, sex, language, religion, political or other opinion, national or social origin, property, birth or other status. 
Article 27. In those States in which ethnic, religious or linguistic minorities exist, persons belonging to such minorities shall not be denied the right, in community with the other members of their group, to enjoy their own culture, to profess and practise their own religion, or to use their own language.

\section{PART IV}

Article 28. - 1. There shall be established a Human Rights Committee (hereafter referred to in the present Covenant as "the Committee"). It shall consist of eighteen members and shall carry out the functions hereinafter provided.

2. The Committee shall be composed of nationals of the State Parties to the present Covenant who shall be persons of high moral character and recognized competence in the field of human rights, consideration being given to the usefulness of the participation of some persons having legal experience.

3. The members of the Committee shall be elected and shall serve in their personal capacity.

Article 29. - 1. The members of the Committee shall be elected by secret ballot from a list of persons possessing the qualifications prescribed in article 28 and nominated for the purpose by the States Parties to the present Covenant.

2. Each State Party to the present Covenant may nominate not more than two persons. These persons shall be nationals of the nominating State.

3. A person shall be eligible for renomination.

Article 30.-1. The initial election shall be held no later than six months after the date of the entry into force of the present Covenant.

2. At least four months before the date of each election of the Committee, other than an election to fill a vacancy declared in accordance with article 34, the Secretary-General of the United Nations shall address a written invitation to the States Parties to the present Covenant to submit their nominations for membership of the Committee within three months.

3. The Secretary-General of the United Nations shall prepare a list in alphabetical order of all the persons thus nominated, with an indication of the States Parties which have nominated them, and shall submit it to the States Parties to the present Covenant no later than one month before the date of each election.

4. Elections of the members of the Committee shall be held at a meeting of the States Parties to the present Covenant convened by the Secretary-General of the United Nations at the Headquarters of the United Nations. At that meeting, for which two thirds of the States Parties to the present Covenant shall constitute a quorum, the persons elected to the Committee shall be those nominees who obtain the largest number of votes and an absolute majority of the votes of the representatives of States Parties present and voting.

Article 31.-1. The Committee may not include more than one national of the same State.

2. In the election of the Committee consideration shall be given to equitable geographical distribution of membership and to the representation of the different forms of civilization as well as of the principal legal systems. 
Article 32. - 1. The members of the Committee shall be elected for a term of four years. They shall be eligible for re-election if renominated. However, the terms of nine of the members elected at the first election shall expire at the end of two years; immediately after the first election the names of these nine members shall be chosen by lot by the Chairman of the meeting referred to in paragraph 4 of article 30 .

2. Elections at the expiry of office shall be held in accordance with the preceding articles of this part of the present Covenant.

Article 33. - 1. If, in the unanimous opinion of the other members, a member of the Committee has ceased to carry out his functions for any cause other than absence of a temporary character, the Chairman of the Committee shall notify the Secretary-General of the United Nations who shall then declare the seat of that member to be vacant.

2 . In the event of the death or the resignation of a member of the Committee, the Chairman shall immediately notify the Secretary-General of the United Nations who shall declare the seat vacant from the date of death or the date on which the resignation takes effect.

Article 34. - 1. When a vacancy is declared in accordance with article 33 and if the term of office of the member to be replaced does not expire within six months of the declaration of the vacancy, the SecretaryGeneral of the United Nations shall notify each of the States Parties to the present Covenant which may within two months submit nominations in accordance with article 29 for the purpose of filling the vacancy.

2. The Secretary-General of the United Nations shall prepare a list in alphabetical order of the persons thus nominated and shall submit it to the States Parties to the present Covenant. The election to fill the vacancy shall then take place in accordance with the relevant provisions of this part of the present Covenant.

3. A member of the Committee elected to fill a vacancy declared in accordance with article 33 shall hold office for the remainder of the term of the member who vacated the seat on the Committee under the provisions of that article.

Article 35. The members of the Committee shall, with the approval of the General Assembly of the United Nations, receive emoluments from United Nations resources on such terms and conditions as the General Assembly may decide having regard to the importance of the Committee's responsibilities.

Article 36. The Secretary-General of the United Nations shall provide the necessary staff and facilities for the effective performance of the functions of the Committee under this Covenant.

Article 37.-1. The Secretary-General of the United Nations shall convene the initial meeting of the Committee at the Headquarters of the United Nations.

2. After its initial meeting, the Committee shall meet at such times as shall be provided in its rules of procedure.

3. The Committee shall normally meet at the Headquarters of the United Nations or at the United Nations Office at Geneva.

Article 38. Every member of the Committee shall, before taking up his duties, make a solemn declaration in open committee that he will perform his functions impartially and conscientiously.

Article 39. - 1. The Committee shall elect its officers for a term of two years. They may be re-elected. 
2. The Committee shall establish its own rules of procedure, but these rules shall provide, inter alia, that:

(a) Twelve members shall constitute a quorum;

(b) Decisions of the Committee shall be made by a majority vote of the members present.

Article 40. - 1. The States Parties to the present Covenant undertake to submit reports on the measures they have adopted which give effect to the rights recognized herein and on the progress made in the enjoyment of those rights; (a) within one year of the entry into force of the present Covenant for the States Parties concerned and (b) thereafter whenever the Committee so requests.

2. All reports shall be submitted to the Secretary-General of the United Nations who shall transmit them to the Committee for consideration. Reports shall indicate the factors and difficulties, if any, affecting the implementation of the present Covenant.

3. The Secretary-General of the United Nations may after consultation with the Committee transmit to the specialized agencies concerned copies of such parts of the reports as may fall within their field of competence.

4. The Committee shall study the reports submitted by the States Parties to the present Covenant. It shall transmit its reports and such general comments as it may consider appropriate to the States Parties. The Committee may also transmit to the Economic and Social Council these comments along with the copies of the reports it has received from States Parties to the present Covenant.

5. The States Parties to the present Covenant may submit to the Committee observations on any comments that may be made in accordance with paragraph 4 of this article.

Article 41. - 1. A State Party to the present Covenant may at any time declare under this article that it recognizes the competence of the Committee to receive and consider communications to the effect that a State Party claims that another State Party is not fulfilling its obligations under the present Covenant. Communications under this article may be received and considered only if submitted by a State Party which has made a declaration recognizing in regard to itself the competence of the Committee. No communication shall be received by the Committee if it concerns a State Party which has not made such a declaration. Communications received under this article shall be dealt with in accordance with the following procedure:

(a) If a State Party to the present Covenant considers that another State Party is not giving effect to the provisions of the present Covenant, it may, by written communication, bring the matter to the attention of that State Party. Within three months after the receipt of the communication, the receiving State shall afford the State which sent the communication an explanation or any other statement in writing clarifying the matter, which should include, to the extent possible and pertinent, reference to domestic procedures and remedies taken, pending, or available in the matter.

(b) If the matter is not adjusted to the satisfaction of both States Parties cuncerned within six months after the receipt by the receiving State of the initial communication, either State shall have the right to refer the matter to the Committee by notice given to the Committee 
and to the other State.

(c) The Committee shall deal with a matter referred to it only after it has ascertained that all available domestic remedies have been invoked and exhausted in the matter, in conformity with the generally recognized principles of international law. This shall not be the rule where the application of the remedies is unreasonably prolonged.

(d) The Committee shall hold closed meetings when examining communications under this article.

(e) Subject to the provisions of sub-paragraph (c), the Committee shall make available its good offices to the States Parties concerned with a view to a friendly solution of the matter on the basis of respect for human rights and fundamental freedoms as recognized in this Covenant.

(f) In any matter referred to it, the Committee may call upon the States Parties concerned, referred to in sub-paragraph (b), to supply any relevant information.

(g) The States Parties concerned, referred to in sub-paragraph (b), shall have the right to be represented when the matter is being considered in the Committee and to make submissions orally and/or in writing.

(h) The Committee shall, within twelve months after the date of receipt of notice under sub-paragraph (b), submit a report:

(i) If a solution within the terms of sub-paragraph (e) is reached, the Committee shall confine its report to a brief statement of the facts and of the solution reached;

(ii) If a solution is not reached, within the terms of sub-paragraph (e), the Committee shall confine its report to a brief statement of the facts; the written submissions and record of the oral submissions made by the States Parties concerned shall be attached to the report.

In every matter the report shall be communicated to the States Parties concerned.

2. The provisions of this article shall come into force when ten States Parties to the present Covenant have made declarations under paragraph 1 of this article. Such declarations shall be deposited by the States Parties with the Secretary-General of the United Nations who shall transmit copies thereof to the other States Parties. A declaration may be withdrawn at any time by notification to the Secretary-General. Such a withdrawal shall not prejudice the consideration of any matter which is the subject of a communication already transmitted under this article; no further communication by any State Party shall be received after the notification of withdrawal of the declaration has been received by the Secretary-General of the United Nations unless the State Party concerned had made a new declaration.

Article 42. - 1. (a) If a matter referred to the Committee in accordance with article 41 is not resolved to the satisfaction of the States Parties concerned, the Committee may, with the prior consent of the States Parties concerned, appoint an ad hoc Conciliation Commission (hereinafter referred to as "the Commission"). The good offices of the Commission shall be made a vailable to the States Parties concerned with a view to an amicable solution of the matter on the basis of respect for the present Covenant;

(b) The Commission shall consist of five persons acceptable to the 
States Parties concerned. If the States Parties concerned fail to reach agreement within three months on all or part of the composition of the Commission the members of the Commission concerning whom no agreement was reached shall be elected by secret ballot by a two-thirds majority vote of the Committee from among its members.

2. The members of the Commission shall serve in their personal capacity. They shall not be nationals of the States Parties concerned, or of a State not party to the present Covenant, or of a State Party which has not made a declaration under article 41 .

3. The Commission shall elect its own Chairman and adopt its own rules of procedure.

4. The meetings of the Commission shall normally be held at the Headquarters of the United Nations or at the United Nations Office at Geneva. However, they may be held at such other covenient places as the Commission may determine in consultation with the Secretary-General of the United Nations and the States Parties concerned.

5. The secretariat provided in accordance with article 36 shall also service the Commissions appointed under this article.

6. The information received and collated by the Committee shall be made available to the Commission and the Commission may call upon the States Parties concerned to supply any other relevant information.

7. When the Commission has fully considered the matter, but in any event not later than twelve months after having been seized of the matter, it shall submit to the Chairman of the Committee a report for communication to the States Parties concerned.

(a) If the Commission is unable to complete its consideration of the matter within twelve months, it shall confine its report to a brief statement of the status of its consideration of the matter.

(b) If an amicable solution to the matter on the basis of respect for human rights as recognized in the present Covenant is reached, the Commission shall confine its report to a brief statement of the facts and of the solution reached.

(c) If a solution within the terms of sub-paragraph (b) is not reached, the Commission's report shall embody its findings on all questions of fact relevant to the issues between the States Parties concerned, as well as its views on the possibilities of amicable solution of the matter. This report shall also contain the written submissions and a record of the oral submissions made by the States Parties concerned.

(d) If the Commission's report is submitted under sub-paragraph (c), the States Parties concerned shall, within three months of the receipt of the report, inform the Chairman of the Committee whether or not they accept the contents of the report of the Commission.

8. The provisions of this article are without prejudice to the responsibilities of the Committee under article 41.

9. The States Parties concerned shall share equally all the expenses of the members of the Commission in accordance with estimates to be provided by the Secretary-General of the United Nations.

10. The Secretary-General of the United Nations shall be empowered to pay the expenses of the members of the Commission, if necessary, before reimbursement by the States Parties concerned in accordance with paragraph 9 of this article.

Article 43. The members of the Committee and of the ad hoc concilia- 
tion commissions which may be appointed under article 41 , shall be entitled to the facilities, privileges and immunities of experts on mission for the United Nations as laid down in the relevant sections of the Convention on the Privileges and Immunities of the United Nations.

Article 44. The provisions for the implementation of the present Covenant shall apply without prejudice to the procedures prescribed in the field of human rights by or under the constituent instruments and the conventions of the United Nations and of the specialized agencies and shall not prevent the States Parties to the present Covenant from having recourse to other procedures for settling a dispute in accordance with general or special international agreements in force between them.

Article 45. The Committee shall submit to the General Assembly, through the Economic and Social Council, an annual report on its activities.

\section{PART V}

Article 46. Nothing in the present Covenant shall be interpreted as impairing the provisions of the Charter of the United Nations and of the constitutions of the specialized agencies which define the respective responsibilities of the various organs of the United Nations and of the specialized agencies in regard to the matters dealt with in the present Covenant.

Article 4\%. Nothing in the Covenant shall be interpreted as impairing the inherent right of all peoples to enjoy and utilize fully and freely their natural wealth and resources.

\section{PART VI}

Article 48. - 1. The present Covenant is open for signature by any State Member of the United Nations or member of any of its specialized agencies, by any State Party to the Statute of the International Court of Justice, and by any other State which has been invited by the General Assembly of the United Nations to become a party to the present Covenant.

2. The present Covenant is subject to ratification. Instruments of ratification shall be deposited with the Secretary-General of the United Nations.

3. The present Covenant shall be open to accession by any State referred to in paragraph 1 of this article.

4. Accession shall be effected by the deposit of an instrument of accession with the Secretary-General of the United Nations.

5. The Secretary-General of the United Nations shall inform all States which have signed this Covenant or acceded to it of the deposit of each instrument of ratification or accession.

Article 49. - 1. The present Covenant shall enter into force three months after the date of the deposit with the Secretary-General of the United Nations of the thirty-fifth instrument of ratification or instrument of accession.

2. For each State ratifying the present Covenant or acceding to it after the deposit of the thirty-fifth instrument of ratification or instrument of accession, the present Covenant shall enter into force three months after the date of the deposit of its own instrument of ratification or instrument of accession. 
Article 50. The provisions of the present Covenant shall extend to all parts of federal States without any limitations or exceptions.

Article 51. - 1. Any State Party to the present Covenant may propose an amendment and file it with the Secretary-General of the United Nations. The Secretary-General of the United Nations shall thereupon communicate any proposed amendments to the States Parties to the present Covenant with a request that they notify him whether they favour a conference of States Parties for the purpose of considering and voting upon the proposal. In the event that at least one third of the States Parties favours such a conference the Secretary-General of the United Nations shall convene the conference under the auspices of the United Nations. Any amendment adopted by a majority of the States Parties present and voting at the conference shall be submitted to the General Assembly of the United Nations for approval.

2. Amendments shall come into force when they have been approved by the General Assembly and accepted by a two-thirds majority of the States Parties to the present Covenant in accordance with their respective constitutional processes.

3. When amendments come into force they shall be binding on those States Parties which have accepted them, other States Parties being still bound by the provisions of the present Covenant and any earlier amendment which they have accepted.

Article 52. Irrespective of the notifications made under article 48, paragraph 5, the Secretary-General of the United Nations shall inform all States referred to in paragraph 1 of the same article of the following particulars:

(a) Signatures, ratifications and accessions under article 48;

(b) The date of the entry into force of the present Covenant under article 49 and the date of the entry into force of any amendments under article 51 .

Article 53. - 1. The present Covenant, of which the Chinese, English, French, Russian and Spanish texts are equally authentic, shall be deposited in the archives of the United Nations.

2. The Secretary-General of the United Nations shall transmit certified copies of the present Covenant to all States referred to in article 48.

\section{OPTIONAL PROTOCOL TO THE INTERNATIONAL COVENANT ON CIVIL AND POLITICAL RIGHTS}

The States Parties to the present Protocol,

Considering that in order further to achieve the purposes of the Covenant on Civil and Political Rights (hereinafter referred to as "the Covenant") and the implementation of its provisions it would be appropriate to enable the Human Rights Committee set up in part IV of the Covenant (hereinafter referred to as "the Committee") to receive and consider, as provided in the present Protocol, communications from individuals claiming to be victims of violations of any of the rights set forth in the Covenant,

Have agreed as follows:

Article 1. A State Party to the Covenant that becomes a party to the present Protocol recognizes the competence of the Committee to receive and consider communications from individuals, subject to its jurisdiction, claiming to be victims of a violation by that State Party of any of the rights 
set forth in the Covenant. No communication shall be received by the Committee if it concerns a State Party to the Covenant which is not a Party to the present Protocol.

Article 2. Subject to the provision of article 1, individuals claiming that any of their rights enumerated in the Covenant have been violated and who have exhausted all available domestic remedies may submit a written communication to the Committee for consideration.

Article 3. The Committee shall consider inadmissible any communication under this Protocol which is anonymous, or which it considers to be an abuse of the right of submission of such communications or to be incompatible with the provisions of the Covenant.

Article 4. - 1. Subject to the provisions of article 3, the Committee shall bring any communications submitted to it under the present Protocol to the attention of the State Party to the present Protocol alleged to be violating any provision of the Covenant.

2. Within six months, the receiving State shall submit to the Committee written explanations or statements clarifying the matter and the remedy, if any, that may have been taken by that State.

Article 5. -1 . The Committee shall consider communications received under the present Protocol in the light of all written information made available to it by the individual and by the State Party concerned.

2. The Committee shall not consider any communication from an individual unless it has ascertained that:

(a) the same matter is not being examined under another procedure of international investigation or settlement;

(b) the individual has exhausted all available domestic remedies.

This shall not be the rule where the application of the remedies is unreasonably prolonged.

3. The Committee shall hold closed meetings when examining communications under the present Protocol.

4. The Committee shall forward its views to the State Party concerned and to the individual.

Article 6. The Committee shall include in its annual report under article $\mathbf{4 5}$ of the Covenant a summary of its activities under the present Protocol.

Article 7. Pending the achievement of the objectives of General Assembly resolution 1514 (XV) of 14 December 1960 concerning the Declaration on the Granting of Independence to Colonial Countries and Peoples, the provisions of the present Protocol shall in no way limit the right of petition granted to these peoples by the Charter of the United $\mathrm{Na}$ tions and other international conventions and instruments under the United Nations and its specialized agencies.

Article 8. - 1. The present Protocol is open for signature by any State which has signed the Covenant.

2. The present Protocol is subject to ratification by any State which has ratified or acceded to the Covenant Instruments of ratification shall be deposited with the Secretary-General of the United Nations.

3. The present Protocol shall be open to accession by any State which has ratified or acceded to the Covenant.

4. Accession shall be effected by the deposit of an instrument of accession with the Secretary-General of the United Nations. 
5. The Secretary-General of the United Nations shall inform all States which have signed the present Protocol or acceded to it of the deposit of each instrument of ratification or accession.

Article 9. - 1. Subject to the entry into force of the Covenant, the present Protocol shall enter into force three months after the date of the deposit with the Secretary-General of the United Nations of the tenth instrument of ratification or instrument of accession.

2. For each State ratifying the present Protocol or acceding to it after the deposit of the tenth instrument of ratification or instrument of accession, the present Protocol shall enter into force three months after the date of the deposit of its own instrument of ratification or instrument of accession.

Article 10. The provision of the present Protocol shall extend to all parts of federal States without any limitations or exceptions.

Article 11. - 1. Any State Party to the present Protocol may propose an amendment and file it with the Secretary-General of the United Nations. The Secretary-General of the United Nations shall thereupon communicate any proposed amendments to the States Parties to the present Protocol with a request that they notify him whether they favour a conference of States Parties for the purpose of considering and voting upon the proposal. In the event that at least one third of the State Parties favours such a conference the Secretary-General of the United Nations shall convene the conference under the auspices of the United Nations. Any amendment adopted by a majority of the States Parties present and voting at the conference shall be submitted to the General Assembly of the United Nations for approval.

2. Amendments shall come into force when they have been approved by the General Assembly and accepted by a two-thirds majority of the States Parties to the present Protocol in accordance with their respective constitutional processes.

3. When amendments come into force they shall be binding on those States Parties which have accepted them, other States Parties being still bound by the provisions of the present Protocol and any earlier amendment which they have accepted.

Article 12. - 1. Any State Party may denounce the present Protocol at any time by written notification addressed to the Secretary-General of the United Nations. Denunciation shall take effect three months after the date of receipt of the notification by the Secretary-General of the United Nations.

2. Denunciation shall be without prejudice to the continued application of the provisions of the present Protocol to any communication submitted under article 2 before the effective date of denunciation.

Article 13. Irrespective of the notifications made under article 8, paragraph 5, of the present Protocol, the Secretary-General of the United Nations shall inform all States referred to in article 48, paragraph 1, of the Covenant of the following particulars:

(a) Signatures, ratifications and accessions under article 8;

(b) The date of the entry into force of the present Protocol under article 9 and the date of the entry into force of any amendments under article 11;

(c) Denunciations under article 12. 
Article 14. - 1. The present Protocol, of which the Chinese, English, French, Russian and Spanish texts are equally authentic, shall be deposited in the archives of the United Nations.

2. The Secretary-General of the United Nations shall transmit certified copies of the present Protocol to all States referred to in article 48 of the Covenant.

\title{
APPENDIX II \\ [EUROPEAN] CONVENTION FOR THE PROTECTION OF HUMAN RIGHTS AND FUNDAMENTAL FREEDOMS
}

\begin{abstract}
The Governments signatory hereto, being Members of the Council of Europe,

Considering the Universal Declaration of Human Rights proclaimed by the General Assembly of the United Nations on 10th December 1948;

Considering that this Declaration aims at securing the universal and effective recognition and observance of the Rights therein declared;

Considering that the aim of the Council of Europe is the achievement of greater unity between its Members and that one of the methods by which that aim is to be pursued is the maintenance and further realisation of Human Rights and Fundamental Freedoms;

Reaffirming their profound belief in those Fundamental Freedoms which are the foundation of justice and peace in the world and are best maintained on the one hand by an effective political democracy and on the other by a common understanding and observance of the Human Rights upon which they depend;

Being resolved, as the Governments of European countries which are like-minded and have a common heritage of political traditions, ideals, freedom and the rule of law, to take the first steps for the collective enforcement of certain of the Rights stated in the Universal Declaration;

Have agreed as follows:
\end{abstract}

\section{Article 1}

The High Contracting Parties shall secure to everyone within their jurisdiction the rights and freedoms defined in Section I of this Convention.

\section{SECTION I \\ Article 2}

(1) Everyone's right to life shall be protected by law. No one shall be deprived of his life intentionally save in the execution of a sentence of a court following his conviction of a crime for which this penalty is provided by law.

(2) Deprivation of life shall not be regarded as inflicted in contravention of this Article when it results from the use of force which is no more than absolutely necessary:

(a) in defence of any person from unlawful violence;

(b) in order to effect a lawful arrest or to prevent the escape of a person lawfully detained;

(c) in action lawfully taken for the purpose of quelling a riot or insurrection. 


\section{Article 3}

No one shall be subjected to torture or to inhuman or degrading treatment or punishment.

\section{Article 4}

(1) No one shall be held in slavery or servitude.

(2) No one shall be required to perform forced or compulsory labour.

(3) For the purpose of this Article the term "forced or compulsory labour" shall not include:

(a) any work required to be done in the ordinary course of detention imposed according to the provisions of Article 5 of this Convention or during conditional release from such detention;

(b) any service of a military character or, in case of conscientious objectors in countries where they are recognised, service exacted instead of compulsory military service;

(c) any service exacted in case of an emergency or calamity threatening the life or well-being of the community;

(d) any work or service which forms part of normal civil obligations.

\section{Article 5}

(1) Everyone has the right to liberty and security of person.

No one shall be deprived of his liberty save in the following cases and in accordance with a procedure prescribed by law:

(a) the lawful detention of a person after conviction by a competent court;

(b) the lawful arrest or detention of a person for non-compliance with the lawful order of a court or in order to secure the fulfilment of any obligation prescribed by law;

(c) the lawful arrest or detention of a person effected for the purpose of bringing him before the competent legal authority on reasonable suspicion of having committed an offence or when it is reasonably considered necessary to prevent his committing an offence or fleeing after having done so;

(d) the detention of a minor by lawful order for the purpose of educational supervision or his lawful detention for the purpose of bringing him before the competent legal authority;

(e) the lawful detention of persons for the prevention of the spreading of infectious diseases, of persons of unsound mind, alcoholic or drug addicts or vagrants;

(f) the lawful arrest of detention of a person to prevent his effecting an unauthorised entry into the country or of a person against whom action is being taken with a view to deportation or extradition.

(2) Everyone who is arrested shall be informed promptly, in a language which he understands, of the reasons for his arrest and of any charge against him.

(3) Everyone arrested or detained in accordance with the provisions of paragraph 1 (c) of this Article shall be brought promptly before a judge or other officer authorised by law to exercise judicial power and shall be entitled to trial within a reasonable time or to release pending trial. Release may be conditioned by guarantees to appear for trial.

(4) Everyone who is deprived of his liberty by arrest or detention shall be entitled to take proceedings by which the lawfulness of his detention shall be decided speedily by a court and his release ordered if the detention is not lawful. 
(5) Everyone who has been the victim of arrest or detention in contravention of the provisions of this Article shall have an enforceable right to compensation.

\section{Article 6}

(1) In the determination of his civil rights and obligations or of any criminal charge against him, everyone is entitled to a fair and public hearing within a reasonable time by an independent and impartial tribunal established by law. Judgment shall be pronounced publicly but the press and public may be excluded from all or part of the trial in the interests of morals, public order or national security in a democratic society, where the interests of juveniles or the protection of the private life of the parties so require, or to the extent strictly necessary in the opinion of the court in special circumstances where publicity would prejudice the interests of justice.

(2) Everyone charged with a criminal offence shall be presumed innocent until proved guilty according to law.

(3) Everyone charged with a criminal offence has the following minimum rights:

(a) to be informed promptly, in a language which he understands and in detail, of the nature and cause of the accusation against him;

(b) to have adequate time and facilities for the preparation of his defence;

(c) to defend himself in person or through legal assistance of his own choosing or, if he has not sufficient means to pay for legal assistance, to be given it free when the interests of justice so require;

(d) to examine or have examined witnesses against him and to obtain the attendance and examination of witnesses on his behalf under the same conditions as witnesses against him;

(e) to have the free assistance of an interpreter if he cannot understand or speak the language used in court.

\section{Article 7}

(1) No one shall be held guilty of any criminal of fence on account of any act or omission which did not constitute a criminal offence under national or international law at the time when it was committed. Nor shall a heavier penalty be imposed than the one that was applicable at the time the criminal offence was committed.

(2) This Article shall not prejudice the trial and punishment of any person for any act or omission which, at the time when it was committed, was criminal according to the general principles of law recognised by civilised nations.

\section{Article 8}

(1) Everyone has the right to respect for his private and family life, his home and his correspondence.

(2) There shall be no interference by a public authority with the exercise of this right except such as is in accordance with the law and is necessary in a democratic society in the interests of national security, public safety or the economic well-being of the country, for the prevention of disorder or crime, for the protection of health or morals, or for the protection of the rights and freedoms of others. 


\section{Article 9}

(1) Everyone has the right to freedom of thought, conscience and religion; this right includes freedom to change his religion or belief and freedom, either alone or in community with others and in public or private, to manifest his religion or belief, in worship, teaching, practice and observance.

(2) Freedom to manifest one's religion or beliefs shall be subject only to such limitations as are prescribed by law and are necessary in a democratic society in the interests of public safety, for the protection of public order, health or morals, or for the protection of the rights and freedoms of others.

\section{Article 10}

(1) Everyone has the right to freedom of expression. This right shall include freedom to hold opinions and to receive and impart information and ideas without interference by public authority and regardless of frontiers. This Article shall not prevent States from requiring the licensing of broadcasting, television or cinema enterprises.

(2) The exercise of these freedoms, since it carries with it duties and responsibilities, may be subject to such formalities, conditions, restrictions or penalties as are prescribed by law and are necessary in a democratic society, in the interests of national security, territorial integrity or public safety, for the prevention of disorder or crime, for the protection of health or morals, for the protection of the reputation or rights of others, for preventing the disclosure of information received in confidence, or for maintaining the authority and impartiality of the judiciary.

\section{Article 11}

(1) Everyone has the right to freedom of peaceful assembly and to freedom of association with others, including the right to form and to join trade unions for the protection of his interests.

(2) No restrictions shall be placed on the exercise of these rights other than such as are prescribed by law and are necessary in a democratic society in the interests of national security or public safety, for the prevention of disorder or crime, for the protection of health or morals or for the protection of the rights and freedoms of others. This Article shall not prevent the imposition of lawful restrictions on the exercise of these rights by members of the armed forces, of the police or of the administration of the State.

\section{Article 12}

Men and women of marriageable age have the right to marry and to found a family, according to the national laws governing the exercise of this right.

\section{Article 13}

Everyone whose rights and freedoms as set forth in this Convention are violated shall have an effective remedy before a national authority notwithstanding that the violation has been committed by persons acting in an official capacity. 


\section{Article 14}

The enjoyment of the rights and freedoms set forth in this Convention shall be secured without discrimination on any ground such as sex, race, colour, language, religion, political or other opinion, national or social origin, association with a national minority, property, birth or other status.

\section{Article 15}

(1) In time of war or other public emergency threatening the life of the nation any High Contracting Party may take measures derogating from its obligations under this Convention to the extent strictly required by the exigencies of the situation, provided that such measures are not inconsistent with its other obligations under international law.

(2) No derogation from Article 2, except in respect of deaths resulting from lawful acts of war, or from Articles 3, 4 (paragraph 1) and 7 shall be made under this provision.

(3) Any High Contracting Party availing itself of this right of derogation shall keep the Secretary-General of the Council of Europe fully informed of the measures which it has taken and the reasons therefor. It shall also inform the Secretary-General of the Council of Europe when such measures have ceased to operate and the provisions of the Convention are again being fully executed.

\section{Article 16}

Nothing in Articles 10,11 and 14 shall be regarded as preventing the High Contracting Parties from imposing restrictions on the political activity of aliens.

\section{Article 17}

Nothing in this Convention may be interpreted as implying for any State, group or person any right to engage in any activity or perform any act aimed at the destruction of any of the rights and freedoms set forth herein or at their limitation to a greater extent than is provided for in the Convention.

Article 18

The restrictions permitted under this Convention to the said rights and freedoms shall not be applied for any purpose other than those for which they have been prescribed.

\section{SECTION II}

\section{Article 19}

To ensure the observance of the engagements undertaken by the High Contracting Parties in the present Convention, there shall be set up:

(1) A European Commission of Human Rights hereinafter referred to as "the Commission";

(2) A European Court of Human Rights, hereinafter referred to as "the Court."

\section{SECTION III}

Article 20

The Commission shall consist of a number of members equal to that of the High Contracting Parties. No two members of the Commission may be nationals of the same State. 


\section{Article 21}

(1) The members of the Commission shall be elected by the Committee of Ministers by an absolute majority of votes, from a list of names drawn up by the Bureau of Consultative Assembly; each group of the Representatives of the High Contracting Parties in the Consultative Assembly shall put forward three candidates, of whom two at least shall be its nationals.

(2) As far as applicable, the same procedure shall be followed to complete the Commission in the event of other States subsequently becoming Parties to this Convention, and in filling casual vacancies.

\section{Article 22}

(1) The members of the Commissin shall be elected for a period of six years. They may be re-elected. However, of the members elected at the first election, the terms of seven members shall expire at the end of three years.

(2) The members whose terms are to expire at the end of the initial period of three years shall be chosen by lot by the Secretary-General of the Council of Europe immediately after the first election has been completed.

(3) A member of the Commission elected to replace a member whose term of office has not expired shall hold office for the remainder of his predecessor's term.

(4) The members of the Commission shall hold office until replaced. After having been replaced, they shall continue to deal with such cases as they already have under consideration.

\section{Article 23}

The members of the Commission shall sit on the Commission in their individual capacity.

\section{Article 24}

Any High Contracting Party may refer to the Commission, through the Secretary-General of the Council of Europe, any alleged breach of the provisions of the Convention by another High Contracting Party.

\section{Article 25}

(1) The Commission may receive petitions addressed to the Secretary-General of the Council of Europe from any person, nongovernmental organisation or group of individuals claiming to be the victim of a violation by one of the High Contracting Parties of the rights set forth in this Convention, provided that the High Contracting Party against which the complaint has been lodged has declared that it recognises the competence of the Commission to receive such petitions. Those of the High Contracting Parties who have made such a declaration undertake not to hinder in any way the effective exercise of this right.

(2) Such declarations may be made for a specific period.

(3) The declarations shall be deposited with the Secretary-General of the Council of Europe who shall transmit copies thereof to the High Contracting Parties and publish them.

(4) The Commission shall only exercise the powers provided for in this Article when at least six High Contracting Parties are bound by declarations made in accordance with the preceding paragraphs. 


\section{Article 26}

The Commission may only deal with the matter after all domestic remedies have been exhausted, according to the generally recognised rules of international law, and within a period of six months from the date on which the final decision was taken.

\section{Article 27}

(1) The Commission shall not deal with any petition submitted under Article 25 which

(a) is anonymous, or

(b) is substantially the same as a matter which has already been examined by the Commission or has already been submitted to another procedure of international investigation or settlement and if it contains no relevant new information.

(2) The Commission shall consider inadmissible any petition submitted under Article 25 which it considers incompatible with the provisions of the present Convention, manifestly ill-founded, or an abuse of the right of petition.

(3) The Commission shall reject any petition referred to it which it considers inadmissible under Article 26.

\section{Article 28}

In the event of the Commission accepting a petition referred to it:

(a) it shall, with a view to ascertaining the facts, undertake together with the representatives of the parties an examination of the petition and, if need be, an investigation, for the effective conduct of which the States concerned shall furnish all necessary facilities, after an exchange of views with the Commission;

(b) it shall place itself at the disposal of the parties concerned with a view to securing a friendly settlement of the matter on the basis of respect for Human Rights as defined in this Convention.

\section{Article 29}

(1) The Commission shall perform the functions set out in Article 28 by means of a Sub-Commission consisting of seven members of the Commission.

(2) Each of the parties concerned may appoint as members of this SubCommission a person of its choice.

(3) The remaining members shall be chosen by lot in accordance with arrangements prescribed in the Rules of Procedure of the Commission.

\section{Article 30}

If the Sub-Commission succeeds in effecting a friendly settlement in accordance with Article 28, it shall draw up a Report which shall be sent to the States concerned, to the Committee of Ministers and to the SecretaryGeneral of the Council of Europe for publication. This Report shall be confined to a brief statement of the facts and of the solution reached.

\section{Article 31}

(1) If a solution is not reached, the Commission shall draw up a Report on the facts and state its opinion as to whether the facts found disclose a breach by the State concerned of its obligations under the Convention. The opinions of all the members of the Commission on this point may be stated in the Report. 
(2) The Report shall be transmitted to the Committee of Ministers. It shall also be transmitted to the States concerned, who shall not be at liberty to publish it.

(3) In transmitting the Report to the Committee of Ministers the Commission may make such proposals as it thinks fit.

\section{Article 32}

(1) If the question is not referred to the Court in accordance with Article 48 of this Convention within a period of three months from the date of the transmission of the Report to the Committee of Ministers, the Committee of Ministers shall decide by a majority of two-thirds of the members entitled to sit on the Committee whether there has been a violation of the Convention.

(2) In the affirmative case the Committee of Ministers shall prescribe a period during which the High Contracting Party concerned must take the measures required by the decision of the Committee of Ministers.

(3) If the High Contracting Party concerned has not taken satisfactory measures within the prescribed period, the Committee of Ministers shall decide by the majority provided for in paragraph (1) above what effect shall be given to its original decision and shall publish the Report.

(4) The High Contracting Parties undertake to regard as binding on them any decision which the Committee of Ministers may take in application of the preceding paragraphs.

\section{Article 33}

The Commission shall meet in camera.

\section{Article 34}

The Commission shall take its decisions by a majority of the Members present and voting; the Sub-Commission shall take its decisions by a majority of its members.

\section{Article 35}

The Commission shall meet as the circumstances require. The meetings shall be convened by the Secretary-General of the Council of Europe.

\section{Article 36}

The Commission shall draw up its own rules of procedure.

\section{Article 37}

The secretariat of the Commission shall be provided by the SecretaryGeneral of the Council of Europe.

\section{SECTION IV}

\section{Article 38}

The European Court of Human Rights shall consist of a number of judges equal to that of the Members of the Council of Europe. No two judges may be nationals of the same State.

\section{Article 39}

(1) The members of the Court shall be elected by the Consultative Assembly by a majority of the votes cast from a list of persons nominated 
by the Members of the Council of Europe; each Member shall nominate three candidates, of whom two at least shall be its nationals.

(2) As far as applicable, the same procedure shall be followed to complete the Court in the event of the admission of new Members of the Council of Europe, and in filling casual vacancies.

(3) The candidates shall be of high moral character and must either possess the qualifications required for appointment to high judicial office or be juris-consults of recognised competence.

\section{Article 40}

(1) The members of the Court shall be elected for a period of nine years. They may be re-elected. However, of the members elected at the first election the terms of four members shall expire at the end of three years, and the terms of four more members shall expire at the end of six years.

(2) The members whose terms are to expire at the end of the initial periods of three and six years shall be chosen by lot by the SecretaryGeneral immediately after the first election has been completed.

(3) A member of the Court elected to replace a member whose term of office has not expired shall hold office for the remainder of his predecessor's term.

(4) The members of the Court shall hold office until replaced. After having been replaced, they shall continue to deal with such cases as they already have under consideration.

\section{Article 41}

The Court shall elect its President and Vice-President for a period of three years. They may be re-elected.

\section{Article 42}

The members of the Court shall receive for each day of duty a compensation to be determined by the Committee of Ministers.

\section{Article 43}

For the consideration of each case brought before it the Court shall consist of a Chamber composed of seven judges. There shall sit as an ex officio member of the Chamber the judge who is a national of any State party concerned, or, if there is none, a person of its choice who shall sit in the capacity of judge; the names of the other judges shall be chosen by lot by the President before the opening of the case.

\section{Article 44}

Only the High Contracting Parties and the Commission shall have the right to bring a case before the Court.

\section{Article 45}

The jurisdiction of the Court shall extend to all cases concerning the interpretation and application of the present Convention which the High Contracting Parties or the Commission shall refer to it in accordance with Article 48.

(1) Any of the High Contracting Parties may at any time declare that it recognises as compulsory ipso facto and without special agreement the 
jurisdiction of the Court in all matters concerning the interpretation and application of the present Convention.

(2) The declarations referred to above may be made unconditionally or on condition of reciprocity on the part of several or certain other High Contracting Parties or for a specified period.

(3) These declarations shall be deposited with the Secretary-General of the Council of Europe who shall transmit copies thereof to the High Contracting Parties.

\section{Article 47}

The Court may only deal with a case after the Commission has acknowledged the failure of efforts for a friendly settlement and within the period of three months provided for in Article 32.

\section{Article 48}

The following may bring a case before the Court, provided that the High Contracting Party concerned, if there is only one, or the High Contracting Parties concerned, if there is more than one, are subject to the compulsory jurisdiction of the Court or, failing that, with the consent of the High Contracting Party concerned, if there is only one, or of the High Contracting Parties concerned if there is more than one:

(a) the Commission;

(b) a High Contracting Party whose national is alleged to be a victim;

(c) a High Contracting Party which referred the case to the Commission;

(d) a High Contracting Party against which the complaint has been lodged.

\section{Article 49}

In the event of dispute as to whether the Court has juridiction, the matter shall be settled by the decision of the Court.

\section{Article 50}

If the Court finds that a decision or a measure taken by a legal authority or any other authority of a High Contracting Party is completely or partially in conflict with the obligations arising from the present Convention, and if the internal law of the said Party allows only partial reparation to be made for the consequences of this decision or measure, the decision of the Court shall, if necessary, afford just satisfaction to the injured party.

\section{Article 51}

(1) Reasons shall be given for the judgment of the Court.

(2) If the judgment does not represent in whole or in part the unanimous opinion of the judges, any judge shall be entitled to deliver a separate opinion.

\section{Article 52}

The judgment of the Court shall be final

\section{Article 53}

The High Contracting Parties undertake to abide by the decision of the Court in any case to which they are parties. 


\section{Article 54}

The judgment of the Court shall be transmitted to the Committee of Ministers which shall supervise its execution.

\section{Article 55}

The Court shall draw up its own rules and shall determine its own procedure.

\section{Article 56}

(1) The first election of the members of the Court shall take place after the declarations by the High Contracting Parties mentioned in Article 46 have reached a total of eight.

(2) No case can be brought before the Court before this election.

\section{SECTION V \\ Article 57}

On receipt of a request from the Secretary-General of the Council of Europe any High Contracting Party shall furnish an explanation of the manner in which its internal law ensures the effective implementation of any of the provisions of this Convention.

\section{Article 58}

The expenses of the Commission and the Court shall be borne by the Council of Europe.

\section{Article 59}

The members of the Commission and of the Court shall be entitled, during the discharge of their functions, to the privileges and immunities provided for in Article 40 of the Statute of the Council of Europe and in the agreements made thereunder.

\section{Article 60}

Nothing in this Convention shall be construed as limiting or derogating from any of the human rights and fundamental freedoms which may be ensured under the laws of any High Contracting Party or under any other agreement to which it is a Party.

\section{Article 61}

Nothing in this Convention shall prejudice the powers conferred on the Committee of Ministers by the Statute of the Council of Europe.

\section{Article 62}

The High Contracting Parties agree that, except by special agreement, they will not avail themselves of treaties, conventions or declarations in force between them for the purpose of submitting, by way of petition, a dispute arising out of the interpretation or application of this Convention to a means of settlement other than those provided for in this Convention.

\section{Article 63}

(1) Any State may at the time of its ratification or at any time thereafter declare by notification addressed to the Secretary-General of the Council of Europe that the present Convention shall extend to all or any of the territories for whose international relations it is responsible. 
(2) The Convention shall extend to the territory or territories named in the notification as from the thirtieth day after the receipt of this notification by the Secretary-General of the Council of Europe.

(3) The provisions of this Convention shall be applied in such territories with due regard, however, to local requirements.

(4) Any State which has made a declaration in accordance with paragraph 1 of this Article may at any time thereafter declare on behalf of one or more of the territories to which the declaration relates that it accepts the competence of the Commission to receive petitions from individuals, non-governmental organisations or groups of individuals in accordance with Article 25 of the present Convention.

\section{Article 64}

(1) Any State may, when signing this Convention or when depositing its instrument of ratification, make a reservation in respect of any particular provision of the Convention to the extent that any law then in force in its territory is not in conformity with the provision. Reservations of a general character shall not be permitted under this Article.

(2) Any reservation made under this Article shall contain a brief statement of the law concerned.

\section{Article 65}

(1) A High Contracting Party may denounce the present Convention only after the expiry of five years from the date on which it became a Party to it and after six months' notice contained in a notification addressed to the Secretary-General of the Council of Europe, who shall inform the other High Contracting Parties.

(2) Such a denunciation shall not have the effect of releasing the High Contracting Party concerned from its obligations under this Convention in respect of any act which, being capable of constituting a violation of such obligations, may have been performed by it before the date at which the denunciation became effective.

(3) Any High Contracting Party which shall cease to be a Member of the Council of Europe shall cease to be a Party to this Convention under the same conditions.

(4) The Convention may be denounced in accordance with the provisions of the preceding paragraphs in respect of any territory to which it has been declared to extend under the terms of Article 63.

\section{Article 66}

(1) This Convention shall be open to the signature of the Members of the Council of Europe. It shall be ratified. Ratifications shall be deposited with the Secretary-General of the Council of Europe.

(2) The present Convention shall come into force after the deposit of ten instruments of ratification.

(3) As regards any signatory ratifying subsequently, the Convention shall come into force at the rate of the deposit of its instrument of ratification.

(4) The Secretary-General of the Council of Europe shall notify all the Members of the Council of Europe of the entry into force of the Convention, the names of the High Contracting Parties who have ratified it, and the deposit of all instruments of ratification which may be effected subsequently. 
NOTE: There have been five protocols to the European Convention for the protection of Human Rights and Fundamental Freedoms. The First Protocol, signed March 20, 1953, added two rights and one obligation to those rights and obligations already in the Convention. The rights added were the right of every natural or legal person to peacefully enjoy possessions, subject to only certain restrictions, and the right to education. The obligation imposed on the High Contracting Parties was to hold free elections at 'reasonable intervals'.

The Second Protocol, signed May 6, 1963, gave the European Court of Human Rights competence to give advisory opinions.

The Third Protocol, signed May 6,1963, made minor changes to the procedure of the European Commission of Human Rights as set out in Articles 29, 30 and 34 of the Convention.

The Fourth Protocol, signed September 16, 1963, added four rights to those rights already in the Convention. First, the Protocol provided that no one should be deprived of liberty merely because of an inability to fulfil contractual obligations. Second, the Protocol provided, subject to certain restrictions, that everyone law fully within the territory of a state has a right to liberty of movement and freedom to choose a residence, including the right to leave any country, including his own. Third, the Protocol provided that no one should be expelled from a state of which he or she is a national or be prohibited from entering such a state. Finally, the Protocol provided that the collective expulsion of aliens is prohibited.

The Fifth Protocol, signed January 20,1966, made changes concerning the length of the terms of office of the Commission members and of the European Court of Human Rights Judges in Article 22 and 40 of the Convention.

\section{APPENDIX III \\ CANADIAN CHARTER OF RIGHTS AND FREEDOMS}

Whereas Canada is founded upon principles that recognize the supremacy of God and the rule of law:

\section{Guarantee of Rights and Freedoms}

1. The Canadian Charter of Rights and Freedoms guarantees the rights and freedoms set out in it subject only to such reasonable limits prescribed by law as can be demonstrably justified in a free and democratic society.

\section{Fundamental Freedoms}

2. Everyone has the following fundamental freedoms:

(a) freedom of conscience and religion;

(b) freedom of thought, belief, opinion and expression, including freedom of the press and other media of communication;

(c) freedom of peaceful assembly; and

(d) freedom of association.

\section{Democratic Rights}

3. Every citizen of Canada has the right to vote in an election of members of the House of Commons or of a legislative assembly and to be 
qualified for membership therein.

4. (1) No House of Commons and no legislative assembly shall continue for longer than five years from the date fixed for the return of the writs at a general election of its members.

(2) In time of real or apprehended war, invasion or insurrection, a House of Commons may be continued by Parliament and a legislative assembly may be continued by the legislature beyond five years if such continuation is not opposed by the votes of more than one-third of the members of the House of Commons or the legislative assembly, as the case may be.

5. There shall be a sitting of Parliament and of each legislature at least once every twelve months.

\section{Mobility Rights}

6. (1) Every citizen of Canada has the right to enter, remain in and leave Canada.

(2) Every citizen of Canada and every person who has the status of a permanent resident of Canada has the right

(a) to move to and take up residence in any province; and

(b) to pursue the gaining of a livelihood in any province.

(3) The rights specified in subsection (2) are subject to (a) any laws or practices of general application in force in a province other than those that discriminate among persons primarily on the basis of province of present or previous residence; and

(b) any laws providing for reasonable residency requirements as a qualification for the receipt of publicly provided social services.

(4) Subsections (2) and (3) do not preclude any law, program or activity that has as its object the amelioration in a province of conditions of individuals in that province who are socially or economically disadvantaged if the rate of employment in that province is below the rate of employment in Canada.

\section{Legal Rights}

7. Everyone has the right to life, liberty and security of the person and the right not to be deprived thereof except in accordance with the principles of fundamental justice.

8. Everyone has the right to be secure against unreasonable search or seizure.

9. Everyone has the right not to be arbitrarily detained or imprisoned.

10. Everyone has the right on arrest or detention

(a) to be informed promptly of the reasons therefor;

(b) to retain and instruct counsel without delay and to be informed of that right; and

(c) to have the validity of the detention determined by way of habeas corpus and to be released if the detention is not lawful.

11. Any person charged with an offence has the right

(a) to be informed without unreasonable delay of the specific offence;

(b) to be tried within a reasonable time;

(c) not to be compelled to be a witness in proceedings against that person in respect of the offence;

(d) to be presumed innocent until proven guilty according to law in a fair and public hearing by an independent and impartial tribunal; 
(e) not to be denied reasonable bail without just cause;

(f) except in the case of an offence under military law tried before a military tribunal, to the benefit of trial by jury where the maximum punishment for the offence is imprisonment for five years or a more severe punishment;

(g) not to be found guilty on account of any act or omission unless, at the time of the act or omission, it constituted an offence under Canadian or international law or was criminal according to the general principles of law recognized by the community of nations;

(h) if finally acquitted of the offence, not to be tried for it again and, if finally found guilty and punished for the offence, not to be tried or punished for it again; and

(i) if found guilty of the offence and if the punishment for the offence has been varied between the time of commission and the time of sentencing, to the benefit of the lesser punishment.

12. Everyone has the right not to be subjected to any cruel and unusual treatment or punishment.

13. A witness who testifies in any proceedings has the right not to have any incriminating evidence so given used to incriminate that witness in any other proceedings, except in a prosecution for perjury or for the giving of contradictory evidence.

14. A party or witness in any proceedings who does not understand or speak the language in which the proceedings are conducted or who is deaf has the right to the assistance of an interpreter.

\section{Equality Rights}

15. (1) Every individual is equal before and under the law and has the right to the equal protection and equal benefit of the law without discrimination and, in particular, without discrimination based on race, national or ethnic origin, colour, religion, sex, age or mental or physical disability.

(2) Subsection (1) does not preclude any law, program or activity that has as its object the amelioration of conditions of disadvantaged individuals or groups including those that are disadvantaged because of race, national or ethnic origin, colour, religion, sex, age or mental or physical disability.

\section{Official Languages of Canada}

16. (1) English and French are the official languages of Canada and have equality of status and equal rights and privileges as to their use in all institutions of the Parliament and government of Canada.

(2) English and French are the official languages of New Brunswick and have equality of status and equal rights and privileges as to their use in all institutions of the legislature and government of New Brunswick.

(3) Nothing in this Charter limits the authority of Parliament or a legislature to advance the equality of status or use of English and French. 17. (1) Everyone has the right to use English or French in any debates and other proceedings of Parliament.

(2) Everyone has the right to use English or French in any debates and other proceedings of the legislature of New Brunswick. 
18. (1) The statutes, records and journals of Parliament shall be printed and published in English and French and both language versions are equally authoritative.

(2) The statutes, records and journals of the legislature of New Brunswick shall be printed and published in English and French and both language versions are equally authoritative.

19. (1) Either English or French may be used by any person in, or in any pleading in or process issuing from, any court established by Parliament.

(2) Either English or French may be used by any person in, or in any pleading in or process issuing from, any court of New Brunswick.

20. (1) Any member of the public in Canada has the right to communicate with, and to receive available services from, any head or central office of an institution of the Parliament or government of Canada in English or French, and has the same right with respect to any other office of any such institution where

(a) there is a significant demand for communications with and services from that office in such language; or

(b) due to the nature of the office, it is reasonable that communications with and services from that office be available in both English and French.

(2) Any member of the public in New Brunswick has the right to communicate with, and to receive available services from, any office of an institution of the legislature or government of New Brunswick in English or French.

21. Nothing in sections 16 to 20 abrogates or derogates from any right, privilege or obligation with respect to the English and French languages, or either of them, that exists or is continued by virtue of any other provision of the Constitution of Canada.

22. Nothing in sections 16 to 20 abrogates or derogates from any legal or customary right or privilege acquired or enjoyed either before or after the coming into force of this Charter with respect to any language that is not English or French.

\section{Minority Language Educational Rights}

\section{3. (1) Citizens of Canada}

(a) whose first language learned and still understood is that of the English or French linguistic minority population of the province in which they reside, or

(b) who have received their primary school instruction in Canada in English or French and reside in a province where the language in which they received that instruction is the language of the English or French linguistic minority population of the province,

have the right to have their children receive primary and secondary school instruction in that language in that province.

(2) Citizens of Canada of whom any child has received or is receiving primary or secondary school instruction in English or French in Canada, have the right to have all their children receive primary and secondary school instruction in the same language.

(3) The right of eitizens of Canada under subsections (1) and (2) to have their children receive primary and secondary school instruction in the 
language of the English or French linguistic minority population of a province

(a) applies wherever in the province the number of children of citizens who have such a right is sufficient to warrant the provision to them out of public funds of minority language instruction; and

(b) includes, where the number of those children so warrants, the right to have them receive that instruction in minority language educational facilities provided out of public funds.

\section{Enforcement}

24. (1) Anyone whose rights or freedoms, as guaranteed by this Charter, have been infringed or denied may apply to a court of competent jurisdiction to obtain such remedy as the court considers appropriate and just in the circumstances.

(2) Where, in proceedings under subsection (1), a court concludes that evidence was obtained in a manner that infringed or denied any rights or freedoms guaranteed by this Charter, the evidence shall be excluded if it is established that, having regard to all the circumstances, the admission of it in the proceedings would bring the administration of justice into disrepute.

\section{General}

25. The guarantee in this Charter of certain rights and freedoms shall not be construed so as to abrogate or derogate from an aboriginal, treaty or other rights or freedoms that pertain to the aboriginal peoples of Canada including

(a) any rights or freedoms that have been recognized by the Royal Proclamation of October 7,1963 ; and

(b) any rights or freedoms that may be acquired by the aboriginal peoples of Canada by way of land claims settlement.

26. The guarantee in this Charter of certain rights and freedoms shall not be construed as denying the existence of any other rights or freedoms that exist in Canada.

27. This Charter shall be interpreted in a manner consistent with the preservation and enhancement of the multicultural heritage of Canadians.

28. Notwithstanding anything in this Charter, the rights and freedoms referred to in it are guaranteed equally to male and female persons.

29. Nothing in this Charter abrogates or derogates from any rights or privileges guaranteed by or under the Constitution of Canada in respect of denominational, separate or dissentient schools.

30. A reference in this Charter to a province or to the legislative assembly or legislature of a province shall be deemed to include a reference to the Yukon Territory and the Northwest Territories, or to the appropriate legislative authority thereof, as the case may be.

31. Nothing in this Charter extends the legislative powers of any body or authority.

\section{Application of Charter}

32. (1) This Charter applies

(a) to the Parliament and government of Canada in respect to all matters within the authority of Parliament including all matters relating to 
the Yukon Territory and Northwest Territories; and

(b) to the legislature and government of each province in respect of all matters within the authority of the legislature of each province.

(2) Notwithstanding subsection (1), section 15 shall not have effect until three years after this section comes into force.

33. (1) Parliament or the legislature of a province may expressly declare in an Act of Parliament or of the legislature, as the case may be, that the Act or a provision thereof shall operate notwithstanding a provision included in section 2 or sections 7 to 15 of this Charter.

(2) An Act or a provision of an Act in respect of which a declaration made under this section is in effect shall have such operation as it would have but for the provision of this Charter referred to in the declaration.

(3) A declaration made under subsection (1) shall cease to have effect five years after it comes into force or on such earlier date as may be specified in the declaration.

(4) Parliament or a legislature of a province may re-enact a declaration made under subsection (1).

(5) Subsection (3) applies in respect of a re-enactment made under subsection (4).

\section{Citation}

34. This Part may be cited as the Canadian Charter of Rights and Freedoms.

\section{PART II}

\section{RIGHTS OF THE ABORIGINAL PEOPLES OF CANADA}

35. (1) The existing aboriginal and treaty rights of the aboriginal peoples of Canada are hereby recognized and affirmed.

(2) In this Act, "aboriginal peoples of Canada" includes the Indian, Inuit and Metis peoples of Canada. 